\title{
Aggregation and Deposition of Engineered Nanomaterials in Aquatic Environments: Role of Physicochemical Interactions
}

\author{
A Critical Review revised and resubmitted to:
}

Environ. Sci. Technol.

June 2, 2010

\begin{abstract}
ADAMO R. PETOSA ${ }^{1}$, DEB P. JAISI ${ }^{2}$, IVAN R. QUEVEDO ${ }^{1}$, MENACHEM $^{2}$ ELIMELECH $^{2}$ and NATHALIE TUFENKJI ${ }^{1, *}$

${ }^{1}$ Department of Chemical Engineering, McGill University, Montreal, Quebec H3A 2B2, Canada

${ }^{2}$ Department of Chemical Engineering, Environmental Engineering Program, Yale University, New Haven, CT 06520-8286
\end{abstract}

*Corresponding Author. Phone: (514) 398-2999; Fax: (514) 398-6678; E-mail: nathalie.tufenkji@mcgill.ca 


\begin{abstract}
The ever-increasing use of engineered nanomaterials will lead to heightened levels of these materials in the environment. The present review aims to provide a comprehensive overview of current knowledge regarding nanoparticle transport and aggregation in aquatic environments. Nanoparticle aggregation and deposition behavior will dictate particle transport potential and thus the environmental fate and potential ecotoxicological impacts of these materials. In this review, colloidal forces governing nanoparticle deposition and aggregation are outlined. Essential equations used to assess particle-particle and particle-surface interactions, along with Hamaker constants for specific nanoparticles and the attributes exclusive to nanoscale particle interactions are described. Theoretical and experimental approaches for evaluating nanoparticle aggregation and deposition are presented, and the major findings of laboratory studies examining these processes are also summarized. Finally, we describe some of the challenges encountered when attempting to quantify the transport of nanoparticles in aquatic environments.
\end{abstract}




\section{Introduction}

Featuring unique electronic, optical, thermal and photoactive properties, nanomaterials are ideal candidates for a multitude of current and potential industrial applications $(1,2)$. With the rising demand for such materials and an increase in their production, nanoparticle release into the environment is inevitable and exposure more likely. Once present in the biosphere, the novel particles may interact with humans and organisms in an unforeseen fashion (3). Thus, it is essential to elucidate the effects such materials can have on both human and environmental health as a result of exposure via different routes.

Exposure can occur at the production, consumption, and disposal stages of particle life $(4,5)$. Particles either enter the environment directly (e.g., due to unintentional release or for remediation purposes), or indirectly by way of waste incineration plants, sewage treatment plants, and landfills (4, 5). Once released, the particles will interact with each other and with their surrounding environments (be it in air, water or soil) $(6,7)$. While particle release occurs within all of these environments, the present review focuses on nanoparticle deposition and aggregation in aquatic systems.

When released into aquatic environments, nanoparticle behavior is dependent on particlespecific properties (e.g., size, shape, chemical composition, surface charge, and coating), particle state (free or matrix incorporated), the surrounding solution conditions (e.g., $\mathrm{pH}$, ionic strength, ionic composition, natural organic matter content), and hydrodynamic conditions $(1,2)$. Such factors are important in determining whether particles aggregate with other particles or deposit onto various environmental surfaces (2). Recognizing which interactions particles experience under different conditions is essential in predicting their fate in the environment and thus likelihood of exposure.

Under conditions resulting in favorable (non-repulsive) particle-surface interactions, nanomaterials will be less likely to travel extensive distances (8). The opposite holds under unfavorable (repulsive) deposition conditions (8). Additionally, an understanding of particle-particle interactions is also imperative when considering particle transport, as aggregation greatly affects particle behavior in the natural environment (2). Changes in particle size and shape resulting from aggregation may significantly alter transport potential, as well as nanomaterial reactivity and toxicity (1). Whereas nanoparticle transport through aquatic environments is expected to be dominated by random 
Brownian diffusion $(9,10)$, an increased particle size imparted by aggregation may result in particlesurface collisions due to gravitational sedimentation and interception (2, 9). In addition, nanoparticles may associate and aggregate with other naturally-occurring substances, such as organic matter, naturally occurring colloidal matter, and dissolved molecules (e.g. phosphates and sulfates) (I). Finally, nanoparticles may experience chemical transformations when suspended in natural aquatic environments, including oxidation/reduction, partial dissolution, hydrolysis, and biological degradation $(1,11)$. Whether such associations and transformations facilitate nanoparticle transport or augment nanoparticle deposition has not been well examined and will depend on the properties exhibited by the nanoparticles, other naturally-occurring materials and the environmental conditions.

Overall, it is essential to elucidate which physicochemical interactions govern particle-surface and particle-particle interactions under conditions representative of aquatic environments. While a great deal of work analyzing the behavior of micrometer-sized particles in various aquatic environments has been performed, limited data (and quantitative analysis) is available for nanosized particles, both in terms of aggregation (12-56) and deposition $(15,16,20,25,44,57-96)$. As a result, two key questions remain unanswered. First, how do specific particle and environmental properties affect deposition and aggregation? Second, are the current approaches and models used in quantifying colloidal interactions and transport applicable to nanomaterials?

This paper provides critical review and assessment of existing research and approaches examining the deposition and aggregation behavior of engineered nanomaterials in aquatic systems. First, colloidal forces central to nanoparticle deposition and aggregation, including traditional Derjaguin-Landau-Verwey-Overbeek (DLVO), non-DLVO, and nanoparticle-specific interactions are summarized. Next, theoretical and experimental approaches for evaluating nanoparticle aggregation and deposition under both favorable and unfavorable conditions are discussed. Finally, the challenges commonly faced when attempting to quantify the environmental transport of engineered nanoparticles are outlined.

\section{Engineered Nanomaterials in Aquatic Systems: From "A"luminum to “Z”irconium}


The presence of nanomaterials in the environment is not novel. Both fullerenes $\left(\mathrm{C}_{60}\right)$ and carbon nanotubes (CNTs) were discovered in 10,000-year-old polar ice cores (97). However, the current rise in anthropogenic nanomaterial production will result in heightened environmental levels of such

products (4). Nanoparticle release into the biosphere will originate at both point sources (e.g., production sites, landfills, treatment plants) and nonpoint sources (e.g., release into the environment during use and consumption of nanomaterial-containing goods) (2, 4). Global production estimates for nanomaterials range from 350 and 500 tons/yr for CNTs and nano-silver $(n \mathrm{Ag})$, respectively, to 5,000 tons/yr for titanium dioxide $\left(\mathrm{TiO}_{2}\right)$ nanoparticles. Predicted environmental concentrations for these particle types have also been estimated, with soil concentration estimates ranging from 0.01 and $0.02 \mu \mathrm{g} / \mathrm{kg}$ for CNTs and $n \mathrm{Ag}$, respectively, to $0.4 \mu \mathrm{g} / \mathrm{kg}$ for $n \mathrm{TiO}_{2}$ (4).

The intentional injection of nanoparticles into the subsurface for remediation purposes is an additional entry route into the environment (82). It has been demonstrated that nanoscale zero-valent iron $(n \mathrm{ZVI})$ can treat a variety of groundwater contaminants, including pesticides and chlorinated organic solvents (2). While a potentially excellent candidate for large-scale site remediation, the environmental transport, fate, and impact of such particles remains to be determined.

Anthropogenic nanomaterials consist of intentionally manufactured products (referred to as manufactured or engineered nanomaterials) and accidental byproducts resulting from wear, corrosion, waste, and combustion of bulk materials (5). A large variety of engineered organic (carbon-based) and inorganic (includes metallic, bimetallic, metal oxide, and semi-conductor based) particles are currently available. Table S1 in the Supporting Information presents a selection of commonly encountered nanomaterials and their key physicochemical characteristics. As can be noted in Table S1, current manufactured nanomaterials vary significantly in isoelectric point, shape, and composition, with particles containing elements ranging from $\mathrm{Al}$ to $\mathrm{Zr}$. For a more extensive summary describing nanoparticles and their applications, refer to $(1)$. Additionally $(1,4)$, the Woodrow Wilson International Center for Scholars has developed an extensive inventory of consumer products incorporating nanotechnology (http://www.nanotechproject.org/).

\section{Colloidal Forces Governing Nanoparticle Deposition and Aggregation}


Particle-particle interactions and particle-surface interactions play key roles in controlling the aggregation and deposition behavior of nanoparticles in aquatic environments. These interactions have traditionally been described by the DLVO theory of colloidal stability. However, non-DLVO forces such as steric, magnetic, and hydration forces can also play an important role in the aggregation and deposition of engineered nanomaterials.

Traditional Colloidal Interactions. The classical DLVO theory $(98,99)$ of colloidal stability describes the total interaction energy experienced by a nanoparticle when approaching another particle (in the case of aggregation) or a collector surface (in the case of deposition). According to the DLVO theory, the stability of nanoparticles suspended in an aqueous environment can be evaluated as the sum of van der Waals (VDW) and electrical double-layer (EDL) interactions. The resultant interaction energy $\left(V_{\mathrm{T}}\right)$, the sum of VDW and EDL interactions, determines the particle stability as the two surfaces approach one another.

VDW forces result from electrical and magnetic polarizations, yielding a varying electromagnetic field within the media and in the separation distance between the two surfaces. The evaluation of dispersion interactions proposed by Hamaker (100) is based on the assumption that the potential between two surfaces could be represented as the sum of the interactions between pairs of atoms located within the two surfaces (particle or collector). Equations to evaluate VDW interactions are presented in Table 1. In addition, the following relations are required to estimate the effect of an intervening medium " 2 " between two bodies of similar composition (" 1 "; eq 1) or of differing composition (“1” and " 3 "; eq. 2) in the case of deposition (8):

$$
\begin{gathered}
A_{121}=\left(A_{22}^{1 / 2}-A_{11}^{1 / 2}\right)^{2} \\
A_{123}=\left(A_{33}^{1 / 2}-A_{22}^{1 / 2}\right)\left(A_{11}^{1 / 2}-A_{22}^{1 / 2}\right)
\end{gathered}
$$

Here, $A_{123}$ is the overall Hamaker interaction parameter for the deposition of a nanoparticle of composition " 1 " onto a surface of composition " 3 " when suspended in a medium " 2 ". In contrast, $A_{121}$ is the overall Hamaker interaction parameter for the aggregation of two nanoparticles of composition " 1 " when suspended in a medium " 2 ". The Hamaker constants of " 1 ", " 2 ", and " 3 " in 
vacuum - $A_{11}, A_{22}$, and $A_{33}$, respectively — are required for use in these equations. These are readily available for a variety of materials, e.g. $(101,102)$.

In aqueous environments, when particles approach each other (aggregation) or a surface (deposition), the overlap of the diffuse electric double layers results in electrostatic double layer interactions. Widely used equations for the most commonly encountered interaction geometries (i.e., two spherical particles or a spherical particle interacting with a planar surface) are presented in Table 1. These equations are based on the linear superposition approximation (LSA) method that applies for low surface potentials and symmetric electrolytes (103). The LSA is a useful compromise between the constant-charge approximation (CCA) and the constant-potential approximation (CPA), which are not likely to apply in practice.

Tables S2 and S3 provide a list of Hamaker constants corresponding to several common nanomaterials. When used with eq 4, the Hamaker constants presented in Table S2 serve in determining the VDW interactions between a particle and a collector surface (i.e., for deposition). The constants listed in Table S3 can be used with eq 7 to evaluate the VDW interaction between two particles (i.e., aggregation of particles). For the case where the Hamaker constant of a specific nanomaterial is not known, it may be evaluated using eqs 1 and 2 .

Non-DLVO Interactions. Beyond the traditional colloidal interactions considered in the DLVO theory, a number of non-DLVO forces can also influence the stability of a nanoparticle suspension in aqueous environments. The most significant forces encountered by engineered nanomaterials in aqueous media include steric interactions, magnetic forces (for iron-based nanomaterials), and hydration forces.

Generalized expressions describing the extent of steric forces have been derived for particles with adsorbed layers of polymers or surfactants that might lead to steric repulsion. These expressions, also included in Table 1, are based on the Alexander-de Gennes theory $(104,105)$ that is used to evaluate the repulsive steric force and the Derjaguin approximation. Steric interactions can be particularly important for nanoparticles in natural and engineered aquatic environments, as most particles adsorb natural organic matter that is known to stabilize colloids $(67,83)$. 
Certain nanomaterials, such as nano-sized iron, exhibit a magnetic dipole moment, even in the absence of an applied magnetic field (106). For these nanomaterials, the contribution of the magnetic force may dominate the total particle-particle interaction energy thereby leading to aggregation. Equation 9 represents the magnetic interaction energy between equally-sized particles of radius $a_{\mathrm{p}}(106)$ :

$$
V_{M}=-\frac{8 \pi \varepsilon_{0} M^{2} a_{p}{ }^{3}}{9\left(\frac{h}{a_{p}}+2\right)^{3}}
$$

where all the variables are defined in the Nomenclature section.

Some nanoparticles may carry hydrophilic material or functional groups at their surface (e.g., proteins, polysaccharides) that can have significant amounts of bound water that may play a role in the interaction of such particles. The approach of two particles with hydrated surfaces will generally be hindered by an additional repulsive interaction. The range of this interaction is significant compared to the range of EDL repulsion and is expected to have an effect on nanoparticle stability, particularly at high ionic strength (107).

Unique Features of Interactions of Nanoscale Particles. Because of the small size of nanoparticles (less than $100 \mathrm{~nm}$ ), their interaction with solid surfaces or other particles can be quite different than that of larger, micrometer-sized particles. These unique features of interaction of nanoscale particles can influence their transport, deposition, and aggregation in aquatic environments.

(a) Greater influence of geochemical heterogeneities on deposition. Geochemical heterogeneities are prevalent on mineral surfaces in subsurface aquatic environments $(108,109)$. Because of their small size, the interactions of nanomaterials in aquatic environments will be substantially influenced by patchwise geochemical heterogeneities (110). Such geochemical heterogeneities may be an important factor controlling the extent of nanoparticle transport in subsurface environments. The size of the patches relative to the size of the particles is an important factor. Nanoparticles may experience greater sensitivity to patch heterogeneity than micrometer-sized 
particles because nanoparticles will interact with smaller patches. When the nanoparticles are smaller than the size of the patch heterogeneities, the particle deposition rate can be approximated by the patchwise heterogeneity model $(108,109)$. Similar arguments can be made regarding nanoparticle interaction with physical heterogeneities in the form of roughness.

(b) Low energy barrier. The kinetics of particle deposition and aggregation are dependent on the height of the energy barrier (8). Particles that overcome the energy barrier will deposit on a surface or aggregate with another particle in a deep primary energy minimum. The height of the energy barrier for deposition or aggregation is directly dependent on the size of the interacting particles, with smaller particles exhibiting much lower energy barriers $(8,62)$. Therefore, nanoparticles will deposit or aggregate more in primary minimum than micrometer-sized particles. It has been shown that nanoparticles that deposit in primary energy minima are less likely to be released from the surface following changes in solution chemistry, such as reduction of ionic strength or changes in solution $\mathrm{pH}(16)$.

(c) Negligible secondary energy minimum. At the ionic strength of typical natural waters, the interaction energy of particles greater than about $0.5 \mu \mathrm{m}$ interacting with similarly charged particles or surfaces is characterized by a high energy barrier and a secondary energy minimum ( 91 , 111). It has been shown that secondary energy minima play a critical role in the deposition and transport of particles greater than approximately $0.5 \mu \mathrm{m}(69,91)$. Such particles readily deposit in secondary minima, even under conditions where a significant energy barrier exists, resulting in reduced transport in subsurface environments. We also note that deposition or aggregation in secondary energy minima is reversible, as particles are released or disaggregate following reduction in ionic strength or increased hydrodynamic shear (91). Except for aggregation of $n Z V I$ particles that have strong longrange attractive magnetic forces, or metallic nanoparticles with a large Hamaker $\left(A_{121}\right)$ constant (Table S3), secondary energy minima are small for nanoparticles (sizes lower than $100 \mathrm{~nm}$ ) at typical ionic strength of natural waters. Therefore, nanoparticles generally will not experience significant deposition or aggregation in secondary minima, and in the presence of an energy barrier will experience greater transport than micrometer-sized particles. 
(d) Interaction energy for very small nanoparticles or non-spherical particles. The expressions summarized in Table 1 for the calculations of the various sphere-sphere and sphere-plate interaction energies are based on the classic Derjaguin approximation (8). The resulting expressions based on this approximation are valid for large particles and for very short separation distances, much smaller than the radius of the interacting particles. Accurate interaction energies for very small particles can be calculated based on the surface element integration (SEI) technique (112). This technique is particularly important for EDL interactions of small particles and low ionic strength, where $\kappa a_{\mathrm{p}}<1(\kappa$ is the inverse Debye length). The commonly used analytical expressions for EDL interactions (summarized in Table 1) are valid only for $\kappa a_{\mathrm{p}}>>1(8)$. The surface element integration can also be applied to describe the interaction energies of non-spherical particles (113), which in principle can be extended to carbon nanotubes.

\section{Quantitative Approaches to Evaluate Nanoparticle Aggregation}

Three transport mechanisms govern the collision of particles during aggregation: Brownian diffusion (perikinetic aggregation), fluid motion (orthokinetic aggregation), and differential settling. For nanoparticles, Brownian diffusion is the predominant mechanism of aggregation with negligible contributions from fluid shear and sedimentation. The Smoluchowski result for the perikinetic aggregation rate constant $\left(k_{\mathrm{ij}}\right)$ for spherical nanoparticles is given by $(8)$ :

$$
k_{i j}=\frac{2 k_{B} T}{3 \mu} \frac{\left(a_{i}+a_{j}\right)^{2}}{a_{i} a_{j}}
$$

For nanoparticles of nearly equal size, the rate constant reduces to:

$$
k_{i i}=\frac{8 k_{B} T}{3 \mu}
$$

For nanoparticles in aqueous solutions at $25^{\circ} \mathrm{C}$, the rate constant for collision of nanoparticles, $k_{\mathrm{i}}$, is $1.23 \times 10^{-17} \mathrm{~m}^{3} / \mathrm{s}$.

Eqs 10 and 11 highlight two important features. First, for nanoparticles of equal size, the rate constant $k_{\mathrm{ii}}$ is independent of particle size. This surprising result is because increasing particle size leads to a lower diffusion coefficient but also to a larger collision radius, such that these two effects 
cancel each other (8). The second important feature (eq 10) is that for particles of different size, the aggregation rate constant will always be greater than that for equal-size particles, which may be significant when small nanoparticles aggregate with much larger suspended particles in aquatic environments.

Unfavorable (Slow) Aggregation. Under unfavorable solution chemistry conditions, where repulsive interactions dominate, nanoparticle aggregation is "slow" or "reaction-limited". Theoretical and experimental approaches to evaluate unfavorable aggregation are summarized briefly below.

(a) Theoretical approaches. The aggregation rate of nanomaterials decreases in the presence of repulsive interactions, such as electrostatic or steric repulsion. In this case, the fraction of successful collisions, $\alpha_{\mathrm{a}}$, often referred to as collision or attachment efficiency, needs to be incorporated into rate equations describing nanoparticle aggregation. When only EDL repulsion and VDW attraction are considered, the stability ratio, $W\left(=1 / \alpha_{\mathrm{a}}\right)$, for spherical nanoparticles of equal size is given by the Fuchs equation (114):

$$
W=\frac{1}{\alpha_{a}}=2 \int_{0}^{\infty} \frac{\exp \left(V_{T} / k_{B} T\right)}{\left(2 a_{p}+h\right)^{2}} d h
$$

A simple approximation of this equation is given by $(8)$ :

$$
\alpha_{a} \approx 2 \kappa a_{p} \exp \left(-\frac{V_{\text {max }}}{k_{B} T}\right)
$$

Because of the exponential dependence of $\alpha_{\mathrm{a}}$ on $V_{\max }$, the equation predicts very low attachment efficiencies for energy barriers above a few $k_{\mathrm{B}} T$. This equation also predicts that small changes in electrolyte concentration can have a dramatic effect on the rate of aggregation. Previous aggregation kinetics studies (e.g. (8), (115)) reveal that eq 12 markedly underpredicts the attachment efficiency of a wide range of colloidal particles, attributing the discrepancy to physical and chemical heterogeneities of particle surfaces as well as aggregation in secondary minima (116). Recent studies 
with $n \mathrm{C}_{60}$, however, demonstrated remarkable agreement between experimental results of aggregation kinetics and theoretical predictions $(16,18)$.

Note that the above analysis does not consider the role of hydrodynamic interactions. It is possible to incorporate the role of hydrodynamic interaction in the Fuchs' integral equation $(8,16)$. Such analysis has been successfully applied for the aggregation kinetics of $n \mathrm{C}_{60}$ by Chen and Elimelech $(16,18)$. Incorporation of hydrodynamic interaction in eq 12 , however, has only a small effect on the attachment efficiency, $\alpha_{\mathrm{a}}$, reducing it by a factor of two or less.

We note that the theoretical approaches for nanoparticle aggregation (as well as nanoparticle deposition to be discussed later) are limited to spherical or, in practice, near-spherical nanoparticles. While these approaches are adequate for most engineered nanoparticles, a notable class of nanomaterials, namely carbon nanotubes (CNTs), cannot be treated with these approaches. CNTs have a very large aspect ratio (i.e., ratio of length to diameter), that often exceeds 1000. CNTs, particularly SWNTs, are also bundled and are not in the form of separate nanotubes in aquatic environments. The complex nature of CNTs precludes the use of useful theories to predict their aggregation (or deposition) behavior. Hence, experimental approaches, as those described below, are often used to describe their aggregation (or deposition) kinetics.

(b) Experimental approaches. Several methods are available to monitor the rate of aggregation of nanomaterials. Among these methods are dynamic light scattering (DLS), small angle light scattering (SALS), and fluorescence correlation spectroscopy (FCS).

Dynamic light scattering (DLS). DLS is the most common method to quantify the aggregation rate of nanomaterials. This technique is also known as photon correlation spectroscopy (PCS) or quasi-elastic light scattering (QELS). In this technique, the diffusion coefficient of aggregating nanoparticles is determined from the autocorrelation function obtained from the fluctuations of the scattered light intensity as a result of the Brownian motion of nanoparticles. The effective aggregate size is calculated from the diffusion coefficient using the Stokes-Einstein equation. DLS has been used to determine aggregation kinetics of a wide variety of nanomaterials (Table 2). 
Small-angle light scattering (SALS). At very low scattering angles, the forward scattering intensity is proportional to the square of the particle/aggregate volume, and is independent of their shape or orientation. Although the form factor tends to be unity for all scattering angles for small nanoparticles, it varies significantly at high scattering angles for nanoparticle aggregate size of $100 \mathrm{~nm}$ or more (117). Therefore, SALS can be useful to derive absolute aggregation rate constants for nanomaterials.

Fluorescence correlation spectroscopy (FCS). In this approach, the particle/aggregate diffusion coefficient is determined for fluorescently-labeled particles passing through an optically-defined confocal volume. Temporal fluctuations in the measured fluorescence intensity are used to derive an autocorrelation curve which is related to the translational diffusion of the fluorophore through the confocal volume (118). FCS has been used to determine the diffusion coefficients and aggregation behavior of QDs, $n \mathrm{TiO}_{2}$, and $n \mathrm{ZnO}(43,119)$.

Favorable (Fast) Aggregation. Under favorable solution chemistry conditions, in the absence of repulsive energy barriers, nanoparticle aggregation is "fast" or "diffusion-limited". Theoretical and experimental approaches to evaluate favorable aggregation are briefly outlined below.

(a) Theoretical approaches. The transition from unfavorable to favorable aggregation occurs over a very narrow range of electrolyte concentration, at the salt concentration where the energy barrier for successful collision vanishes. This behavior can, in principle, be predicted from eq 12 . The salt concentration corresponding to this transition is called the critical coagulation concentration (CCC). The magnitude of the CCC depends on the counterion valence $(z)$, the nanoparticle zeta potential $(\zeta)$, and the Hamaker constant $A_{121}$ according to (8):

$$
C C C \propto \frac{1}{z^{6} A_{121}{ }^{2}} \tanh ^{4}\left(\frac{z e \zeta}{4 k_{B} T}\right)
$$

This equation shows that at large zeta potentials (i.e., ze $\zeta / 4 k_{B} T>>1$ ), the CCC is proportional to $z^{-6}$. This relationship is known as the Schulze-Hardy rule. However, at low zeta potentials (i.e. $z e \zeta / 4 k_{B} T<<1$ ), which is common for different engineered nanomaterials, the CCC is proportional 
to $z^{-2}$. In practice, the CCC dependence on $z$ for a wide range of nanomaterials should be in between $z^{-6}$ to $z^{-2}$.

(b) Experimental approaches. The fast aggregation rate constant can be determined from any of the methods described earlier when carrying out aggregation experiments at high salt concentrations, above the CCC. Once the favorable aggregation rate is determined, the collision (attachment) efficiency, $\alpha_{\mathrm{a}}$, can be determined by normalizing the aggregation rate constant obtained at a given solution chemistry with the favorable aggregation rate constant. For instance, when using DLS, $\alpha_{\mathrm{a}}$ can be obtained from the slopes of the initial change of the hydrodynamic radius with time $(17,120)$ :

$$
\alpha_{a}=\frac{\frac{1}{N_{0}}\left(\frac{d a_{h}(t)}{d t}\right)_{t \rightarrow 0}}{\frac{1}{N_{0, f a v}}\left(\frac{d a_{h}(t)}{d t}\right)_{t \rightarrow 0, f a v}}
$$

where the subscript "fav" denotes favorable aggregation. This experimental approach can be used to determine the attachment efficiency of all types of nanomaterials, including non-spherical nanomaterials such as CNTs.

\section{Quantitative Approaches to Evaluate Nanoparticle Deposition}

The transport and deposition of nanoparticles in saturated granular porous media is generally governed by Brownian diffusion $(68,78)$, with negligible contributions from gravitational sedimentation and interception. The importance of Brownian diffusion increases with decreasing particle size, thereby increasing the number of collisions between nanoparticles and collector (e.g., aquifer grain) surfaces. Particle deposition onto a collector surface depends on a number of factors, including particle and grain sizes, particle and collector surface potentials, solution chemistry of the suspending medium, and the Hamaker constant of the particle-fluid-collector (8). In natural or engineered aquatic environments, the interactions between nanoparticles and collector surfaces — generally described by 
the DLVO theory of colloidal stability — can either be attractive or repulsive. The particle attachment efficiency $\left(\alpha_{\mathrm{d}}\right)$ is a parameter that relates the particle deposition rate measured under favorable conditions to that measured under unfavorable conditions (78):

$$
\eta=\alpha_{\mathrm{d}} \eta_{0}
$$

Unfavorable (Slow) Deposition. Analogous with aggregation, the dominating repulsive interactions encountered under unfavorable solution chemistries result in limited nanoparticle deposition. For deposition to occur under such conditions, sizable energy barriers between colloid and collector surfaces must be overcome. Theoretical and experimental approaches used to evaluate unfavorable deposition are summarized below.

(a) Theoretical approach. The most common approach in predicting nanoparticle deposition rates under unfavorable conditions is the interaction force boundary layer (IFBL) approximation $(121,122)$. In this approach, the region adjacent to a collector surface is divided into an inner layer (the IFBL) and an outer layer. The inner region thickness $\left(\delta_{\mathrm{F}}\right)$ corresponds to that of the EDL, while the width of the outer region $\left(\delta_{\mathrm{D}}\right)$ scales with the diffusion boundary layer. The IFBL approximation assumes that $\delta_{\mathrm{D}}$ is far thicker than $\delta_{\mathrm{F}}$ and that deposition of nanoparticles due to interception and gravitational sedimentation is negligible. Relevant IFBL equations are (8):

$$
\eta=4.0 A_{S}^{1 / 3}\left(\frac{D_{\infty}}{2 a_{c} U}\right)^{2 / 3}\left(\frac{\beta}{1+\beta}\right) S(\beta)
$$

where $\beta$ in the above equation is given by:

$$
\beta=\frac{1}{3}(2)^{1 / 3} \Gamma\left(\frac{1}{3}\right) A_{s}^{-1 / 3}\left(\frac{D_{\infty}}{U a_{c}}\right)^{1 / 3}\left(\frac{K_{F} a_{c}}{D_{\infty}}\right)
$$

Here, $K_{\mathrm{F}}$ is the pseudo-first order rate constant $(8)$ :

$$
K_{F}=D_{\infty}\left\{\int_{0}^{\delta_{D}}\left[g_{1}(H) \exp \left(V_{T} / k_{B} T\right)-1\right] d y\right\}^{-1}
$$

Similar to the analysis of unfavorable aggregation (eqs 12 and 13), the deposition rate is very sensitive to $V_{\mathrm{T}} / k_{\mathrm{B}} T$. Previous deposition kinetics studies indicate that eq 17 markedly underpredicts 
the deposition rate for a wide range of colloidal particles and collector surfaces (8). This discrepancy is commonly attributed to chemical and physical heterogeneities of particle and collector surfaces as well as deposition in secondary minima.

(b) Experimental approaches. There exist two main experimental approaches to evaluate nanoparticle deposition rates onto collector surfaces in aqueous environments. The most commonly used approach is the laboratory-scale packed-bed column experiment $(15,61,65,78-80,91)$. Another experimental technique that has recently been used to study nanoparticle deposition kinetics is the quartz crystal microbalance (QCM) $(66,85)$. Laboratory column studies are performed using columns packed with granular materials (e.g., glass beads, sand, or soil) and injecting the particles of interest at a known influent concentration, $C_{0}$, for a time period $t_{0}$. The particles are generally suspended in natural or artificial (model) solution chemistry of known composition. Particle retention in the packed-bed is evaluated by measuring the effluent particle concentration $(C)$ as a function of time using techniques such as UV-visible and fluorescence spectrophotometry, or flow cytometry. The nanoparticle attachment efficiency is commonly evaluated using colloid filtration theory (CFT) (10):

$$
\alpha_{d}=-\frac{2 d_{c}}{3(1-\varepsilon) \eta_{0} L} \ln \left(C / C_{0}\right)
$$

The single-collector contact efficiency $\left(\eta_{0}\right)$ in eq 20 is determined in the absence of external repulsive forces (favorable conditions) using the experimental or theoretical approaches described below.

Equation 20 is derived from a mass balance for a one-dimensional flow in a packed column when advection is the dominant mechanism of nanoparticle transport. This assumption is adequate for most laboratory column data with nanomaterials, including those described later in this paper. However, under conditions involving very low approach velocities (approximately less than $10^{-6} \mathrm{~m} / \mathrm{s}$ ), this equation is inadequate because transport of nanomaterials by dispersion dominates (123). Under these conditions, one needs to determine the nanoparticle deposition rate constant by fitting the breakthrough curve to the advection-dispersion equation with a first-order deposition rate constant (124). The attachment efficiency is then determined by normalizing the deposition rate constant with the favorable deposition rate constant determined from a similar experiment under favorable conditions or from theoretical approaches described below. 
Alternatively, a pulse technique can be employed to explore the behavior of nanoparticles in packed-bed columns. Once the column has been equilibrated with electrolyte, a single-step injection pulse of nanomaterials of known mass or number concentration is introduced into the column. Assuming a semi-infinite column under clean-bed conditions, the particle concentration, $C(x, t)$, in the column at depth $x$ and time $t$ is given by the one-dimensional advection-dispersion equation $(74,108)$ :

$$
C(x, t)=n_{o} \frac{x}{2 \sqrt{\pi t^{3} D}} \exp \left(-k_{d} t\right) \exp \left[-\frac{(x-v t)^{2}}{4 D t}\right]
$$

A nonlinear least-squares analysis can be employed to fit eq 21 to the breakthrough curves obtained subsequent to the pulse injection. Both $k_{\mathrm{d}}$ and $D$ are obtained simultaneously with this analysis. Again, $\alpha_{\mathrm{d}}$ is determined by normalizing this deposition rate constant with the favorable deposition rate constant determined from a similar experiment conducted under favorable conditions.

The QCM has recently been demonstrated to be useful in measuring the deposition kinetics of nanoparticles onto model collector surfaces $(66,85)$. In this technique, particle deposition occurs on a clean or functionalized silica-coated QCM crystal which is excited to oscillate at its fundamental resonance frequency. As particles deposit onto the crystal, the increase in mass $(m)$ on the collector surface results in measurable decrease in the crystal's resonance frequency $(f)$. For homogeneous, very thin, or quasi-rigid layers, the frequency shift of the oscillating crystal $(\triangle f)$ is directly related to the increase in mass per unit area $\left(\Delta m_{\mathrm{f}}\right)$ by the Sauerbrey relation (125). As the frequency shift $(\Delta f)$ is proportional to a change in mass $\left(\Delta m_{\mathrm{f}}\right)$ at the crystal surface, the rate of change of $\Delta f$ is equivalent to the rate of mass change on the crystal surface (i.e., the rate of particle deposition or release). Hence, the nanoparticle deposition rate $\left(r_{\mathrm{d}}\right)$ can be determined by evaluating the initial slope in the $\Delta f$ measurements (66) using:

$$
r_{d}=\frac{d \Delta f}{d t}
$$

When the QCM flow chamber is designed with a parallel-plate geometry, the SmoluchowskiLevich approximation can be used to evaluate the theoretical particle deposition rate $\left(r_{d}^{S L}\right)$ in the absence of repulsive interactions: 


$$
r_{d}^{S L}=0.538 \frac{D_{\infty} C_{0}}{a_{p}}\left(\frac{P e h_{c}}{x}\right)^{1 / 3}
$$

Two-dimensional microchannel structures have also been used to study nanoparticle deposition $(68,75)$. Photolithography and chemical etching are employed to construct porous microchannels. Particle suspensions of known concentration are injected into the 2-dimensional structure and the effluent concentration exiting the set-up can be determined using various detection methods. Additionally, pore clogging by large nanoparticle aggregates can be visualized by mounting the microchannels onto a microscope stage (68). Parallel-plate flow chambers can also be packed with collector grains, allowing for the visualization of particle deposition and pore clogging. While visualization of nanoparticles in such set-ups is challenging, the behavior of particle aggregates can sometimes be examined by mounting the set-up onto a microscope stage.

Favorable (Fast) Deposition. When deposition is favorable, the nanoparticle deposition rate approaches the mass-transport limited rate. In this case, $\alpha_{\mathrm{d}}$ approaches unity, and $\eta_{=} \eta_{0}$. Several theoretical and experimental approaches have been proposed to evaluate $\eta_{0}$ for nanoparticles and are described here.

(a) Theoretical approaches. The single-collector contact efficiency, $\eta_{0}$, is a ratio between the total rate of particle-collector contacts and the rate at which particles flow towards a collector grain. Particle transport to the grain results from sedimentation, interception, and Brownian diffusion, with diffusion dominating for nanomaterials. The single-collector contact efficiency accounts for particle transport via interception $\left(\eta_{\mathrm{I}}\right)$, gravitational sedimentation $\left(\eta_{\mathrm{G}}\right)$, and Brownian diffusion $\left(\eta_{\mathrm{D}}\right)$ and can be determined by rigorously solving the convective-diffusion equation (9). Semiempirical correlation equations based on numerical solutions of the convective-diffusion equation have been developed (9, 126). A correlation equation developed by Tufenkji and Elimelech overcomes the limitations of previous approaches that are particularly important for nano-sized particles (9). Specifically, this equation considers the influence of hydrodynamic and VDW interactions on Brownian diffusion. Moreover, the impact of VDW forces on the transport of particles by gravitational sedimentation is also considered (9). This latter mechanism can be significant for nanoparticles of high density, such 
as metal oxides. Hence, the single-collector contact efficiency for nanoparticle transport in saturated granular porous media under conditions favorable for deposition can be determined using (9):

$$
\eta_{o}=2.4 A_{s}^{1 / 3} N_{R}^{-0.081} N_{P e}{ }^{-0.715} N_{v d W}{ }^{0.052}+0.55 A_{S} N_{R}^{1.675} N_{A}^{0.125}+0.22 N_{R}^{-0.24} N_{G}^{1.11} N_{v d W}{ }^{0.053}
$$

The dimensionless parameters in eq 24 have all been defined elsewhere (9).

Equation 24 was derived from numerical simulations over a wide range of particle and porous media properties, covering particle diameters as small as $10 \mathrm{~nm}$, approach velocities as low as $7 \times 10^{-6}$ $\mathrm{m} / \mathrm{s}$, and particle densities as high as $1.8 \mathrm{~g} / \mathrm{cm}^{3}$. The correlation equation slightly overestimates $\eta_{0}$ for particle diameters smaller than about $30 \mathrm{~nm}$, and the Smoluchowski-Levich approximation $(8,127)$ should be used for such small particles. This approximation yields predictions almost identical to those obtained from numerical solution of the complete convective-diffusion equation (9):

$$
\eta_{0}=4.04 A_{S}{ }^{1 / 3} N_{P e}^{-2 / 3}
$$

For very small nanoparticles (less than $\sim 10 \mathrm{~nm}$ ) and/or for unusually low approach velocities (on the order of $10^{-6} \mathrm{~m} / \mathrm{s}$ or less), which are rarely encountered in practical applications, eqs 24 or 25 can yield $\eta_{0}$ values greater than 1 , which is physically questionable. Song and Elimelech (128) have analyzed this problem and indicated that $\eta_{0}$ should not exceed 1 . Similarly, at such unusually low approach velocities (on the order of $10^{-6} \mathrm{~m} / \mathrm{s}$ or less) and for nanoparticles with high specific density (like metal oxide nanoparticles), $\eta_{0}$ values greater than 1 can be obtained using eq 24 . Here, again, the upper limit of $\eta_{0}$ should be set to 1 . We note, however, that such conditions of very low approach velocities are rarely encountered in the laboratory or field scale. Furthermore, under such low velocities the deposition rate is so high that the nanoparticles are practically immobile and there is no need to predict their transport.

(b) Experimental approaches. As with unfavorable deposition studies, experiments under favorable conditions can also be performed using packed-bed columns, the QCM, and micromodel flow-cells. Obtaining the favorable or transport-limited particle deposition rate can be beneficial when working with particles that undergo deposition and aggregation simultaneously. Under such conditions, the favorable deposition rate can be used to normalize observed deposition rates in efforts 
to evaluate $\alpha_{\mathrm{d}}$ (57). To obtain favorable deposition (and thus the favorable deposition rate), the colloid and collector surfaces must be oppositely charged. However, this is often not the case with model collector surfaces such as silica sand, as the isoelectric point (IEP) of silica is -2 . Many engineered nanomaterials (e.g., $n \mathrm{SiO}_{2}, n \mathrm{TiO}_{2}$, QDs, $n \mathrm{Au}$, fullerols), also possess low IEPs (Table S1) and, hence, at environmentally relevant $\mathrm{pHs}$, their deposition will be unfavorable. To create favorable conditions for deposition, the collector can be pretreated to create a positively charged surface (e.g., coating with a cationic polymer such as poly-L-lysine (PLL) or aminosilane surface modification) $(108,129)$. These surface treatments can be performed on various collector surfaces that might be used in QCM, packed columns, or micromodel flow-cells.

\section{Current State of Knowledge on Nanoparticle Aggregation and Deposition}

It can be expected that the most mobile nanomaterials will have the greatest impact on the environment, as they are most likely to contact potential receptors. In determining the mobility of any given particle, both aggregation and deposition must be considered. Aggregation and deposition are two closely related processes. The likelihood that either of these processes occurs depends on various interrelated factors. These include particle size and shape, particle and collector surface charges, and the surrounding $\mathrm{pH}$ and solution chemistry. An increase in size due to particle aggregation impacts particle mobility; hence, the time-scale of particle aggregation is an important consideration when conducting nanoparticle deposition studies. The information currently available in the literature on nanomaterial aggregation and deposition has been summarized and critically analyzed below.

\section{Laboratory Studies Examining the Aggregation of Engineered Nanomaterials.}

Table 2 presents a summary of studies involving aggregation of engineered nanomaterials in aquatic systems. This summary includes a wide range of nanomaterials, solution chemistries, and experimental techniques. Several of these studies present quantitative assessment of aggregation rates (16-18, 34, 43) and $\operatorname{CCCs}(16-18,20,24,34,54)$, while others present qualitative aggregation behavior $(12,36$, 44). 
CNT aggregation in aqueous solutions of inorganic electrolytes follows the classic SchulzeHardy rule for colloidal stability (36). Multiwalled carbon nanotubes (MWNTs) have a negative electrophoretic mobility and are relatively stable at solution $\mathrm{pH}$ and electrolyte conditions typical of aquatic environments. Notably, the presence of natural organic matter markedly enhances the stability of MWNTs. Acidic functional groups, usually acquired via chemical treatment $(24,36,53)$, increase the hydrophilicity of CNTs and substantially enhance their colloidal stability. A recent study demonstrated that clay minerals destabilize dispersed MWNTs in solution either by removal of surfactants from MWNT surfaces or by bridging between clay minerals and MWNTs by surfactant molecules (130). In contrast to MWNTs, studies on single-walled carbon nanotube (SWNT) aggregation are limited. SWNTs are highly bundled and are difficult to disperse even by sonication. However, once inter-tube VDW attraction is overcome, adsorption of surfactants, such as SDS, to SWNTs induces significant electrostatic repulsion to prevent SWNT re-aggregation (33). A recent study on SWNT aggregation kinetics has demonstrated that humic substances and biomacromolecules of relevance to biological media impart steric stabilization to SWNTs (131).

The early stages of aggregation of fullerene nanoparticles in the presence of both monovalent and divalent salts are consistent with the DLVO theory of colloidal stability (16-18). The presence of humic acid results in greater stability of $n \mathrm{C}_{60}$ suspensions as a result of steric repulsion (17). In identical polar solvents, the likelihood of aggregation among fullerene nanoparticles is $n \mathrm{C}_{60}>n \mathrm{C}_{70}>n \mathrm{C}_{\text {mix }}$ (132). It was suggested that the original size and crystallographic face/lattice that control packing also play roles in aggregation in both polar solvents and aqueous solutions $(19,133)$. Labille et al. $(134,135)$ found that initially $n \mathrm{C}_{60}$ gradually become hydrophilic due to hydration and surface hydroxylation in the presence of water. It was hypothesized that this mechanism may be responsible for the gradual acquisition of titratable negative surface charge on the otherwise unfunctionalized fullerenes $(134,135)$. However, a recent study indicates that the mechanism of surface charge acquisition by $n \mathrm{C}_{60}$ is still not well understood (18).

Aggregation and stability of CNTs and $n \mathrm{C}_{60}$ depends on their surface properties, electrolyte concentration and type, and the specific adsorption mechanism of macromolecules, polymers, or surfactants. For example, humic and fulvic acid molecules adsorb onto MWNTs by $\pi-\pi$ interactions 
in which cross-linked aromatic networks on the molecules interact with aromatic rings on the MWNTs $(28,136)$. In fact, the sorption capacity and hence the stability of CNTs have been directly correlated to the aromatic content of NOM (136).

The presence of redox sensitive elements in nanoparticle structures may promote their dissolution and transformation. For example, oxidation of Fe in $n \mathrm{ZVI}$ produces a thin shell of hematite $\left(\mathrm{Fe}_{2} \mathrm{O}_{3}\right)$ on the core of $\mathrm{Fe}^{0}$. The physicochemical properties of $n \mathrm{ZVI}$ with thick hematite shells are more likely similar to those of hematite particles. However, because $n$ ZVI are often prepared with polymer and/or surfactant coatings, the properties of the $\mathrm{Fe}_{2} \mathrm{O}_{3}$ shell and $\mathrm{Fe}^{0}$ core play a small role in the aggregation and deposition of $n \mathrm{ZVI}$. The stability and aggregation behavior of $n \mathrm{ZVI}$ has been studied in the presence of different polymers and surfactants $(51,52,54)$. Polymers and surfactants impart steric repulsive forces that oppose the long-range attractive magnetic forces between $n Z V I$ particles. The properties of polymer-coated $n Z V I$ are influenced by the chemical composition and structure of the polymer coating (137). Besides imparting a more negative surface charge due to sorption, surfactants such as poly(vinyl alcohol-co-vinyl acetate-co-itaconic acid), PV3A, also decrease the isoelectric point (53). These results collectively suggest that the properties of $n Z \mathrm{VI}$ are controlled by the characteristics of the surfactant or polymer added to achieve targeted application of $n \mathrm{ZVI}$.

The stability curves in Figure 1 were prepared using the results of published experimental studies examining the aggregation kinetics of selected engineered nanomaterials under different solution conditions. Careful inspection of the data in Figure 1 reveals several interesting insights regarding nanoparticle aggregation behavior. Studies on $n \mathrm{C}_{60}$ aggregation completed by $\mathrm{Chen}$ and Elimelech (18) show how different nanoparticle preparation methods can give rise to significantly differing nanoparticle surface properties and suspension stability (Fig. 1a). The data in Fig. 1a also show that the aggregation behavior of $n \mathrm{C}_{60}$ particles can be comparable even across different laboratories (open square, triangles, and diamond). The solid symbols in Fig. 1a represent results obtained with the $n \mathrm{C}_{60}$ derivatives PCBM ([6,6]-phenyl $\mathrm{C}_{61}$-butyric acid methyl ester) and the corresponding butyl and octyl esters, $\mathrm{PCBB}$ and PCBO. When compared to $n \mathrm{C}_{60}$, the derivatized nanomaterials exhibit considerably greater stability (14). Fig. 1b shows stability curves measured with MWNTs and oxidized MWNTs (O-MWNTs). The work of Smith et al (24) reveals linear 
correlations between the CCC, total surface oxygen concentration (SOC), and surface charge of OMWNTs. They also observed increased stability of O-MWNTs with increasing $\mathrm{pH}$ (square symbols, Fig. 1b). These studies suggest that although individual results may vary, aggregation of engineered nanomaterials, in general, follows the classical behavior of colloidal particles in aquatic systems. We note, for instance, clear trends of increasing values of the aggregation attachment efficiency with increasing solution ionic strength, to a maximum value of 1 when the CCC is reached.

Laboratory Studies Examining the Deposition of Engineered Nanomaterials. To date, laboratory studies examining the transport and deposition of engineered nanomaterials in aqueous environments have been performed using a variety of materials, including metallic, metal oxide, carbon-based, and semi-conductor based particles. These studies are summarized in Table 3, listing the type of experimental approach used in each study, as well as the solution chemistry, and collector and particle surface properties. The key findings of each study are also included. The summary presented suggests that it is not straightforward to draw conclusions from the transport studies performed thus far. Even when considering one type of particle, several factors complicate comparison between studies. These include variability in particle size and concentration, water chemistry (i.e., electrolyte species, ionic strength, and $\mathrm{pH}$ ), flow velocity, and choice of collector surface. Moreover, given the importance of particle surface properties, direct comparisons between experiments involving bare and surface-modified nanoparticles are difficult to make.

Column studies are currently the most commonly used technique to elucidate nanoparticle deposition behavior. Experiments in columns packed with glass beads have indicated that SWNTs are mobile (78). Additionally, carboxylated SWNT transport in packed sand columns generally follows the behavior expected from DLVO theory, with straining limiting mobility at low ionic strength (73). A number of column studies have been performed to analyze the transport and retention of $n \mathrm{C}_{60}$, employing glass beads, sand, and soil $(15,25,59,65,79,80,93)$. At low ionic strength (3 $\mathrm{mM})$, and in the presence of coarser sand $\left(d_{50}=335 \mu \mathrm{m}\right), n \mathrm{C}_{60}$ elutes from packed sand columns with little retention. However, when finer sand $\left(d_{50}=125 \mu \mathrm{m}\right)$ and higher solution ionic strengths $(30 \mathrm{mM})$ are encountered, a majority of the nanoparticles are retained (25). In packed soil columns, $n \mathrm{C}_{60}$ are 
most mobile at higher flow velocities (11.4 and $3.8 \mathrm{~m} /$ day), with only limited nanoparticle mobility and extremely rapid deposition encountered at a lower flow velocity $(0.38 \mathrm{~m} /$ day $)$ representative of groundwater flow (59). Clearly, the choice of granular material, solution chemistry, and flow velocity all play major roles in nanoparticle deposition.

Packed column studies have demonstrated that the transport behavior of $n \mathrm{C}_{60}$ particles is in good qualitative agreement with DLVO theory $(25,80)$. In addition to packed-bed column studies, the QCM has been employed to examine nanoparticle deposition onto and release from surfaces in aquatic environments $(16,57,66,85)$. QCM studies indicate that $n \mathrm{C}_{60}$ deposition behavior is generally consistent with DLVO theory $(16,57)$.

Several studies have also reported the deposition behavior of inorganic nanoparticles (Table 3). Bare and surface-modified $n \mathrm{Al}$ have demonstrated dissimilar deposition behaviors, even though the core material remains the same $(61)$. Column studies with $n Z V I$ also indicate that surface modifications alter nanoparticle deposition behavior (138). A field study involving the injection of bimetallic (Fe/Pd) nanoparticles at a contaminated test site found particle behavior to be in general agreement with classical colloid transport concepts (64). QCM studies have established that the deposition behavior of bare and surface-modified $n \mathrm{ZVI}$ onto silica surfaces is very different, with particles modified with amphiphilic triblock copolymer displaying significantly heightened mobility. QCM data obtained in this study correspond with column transport results (138). However, in these studies, surface-modified $n$ ZVI deposition was not in qualitative agreement with DLVO theory.

Several studies have examined the transport potential of $n \mathrm{TiO}_{2}$ in saturated granular porous media $(60,78,79)$. $n \mathrm{TiO}_{2}$ retention in packed sand columns has been found to be high regardless of particle concentrations and flow velocities (60). Additionally, it appears that distinct transport processes likely occur at different column depths. Attempting to predict titania retention within packed sand columns utilizing an empirical kinetic transport model has indicated that existing models cannot predict $n \mathrm{TiO}_{2}$ particle retention (60). $n \mathrm{TiO}_{2}$ transport has been found to depend on both particle surface potential and particle aggregate size (68). Micromodel flow cell analysis of $n \mathrm{TiO}_{2}$ transport and retention over a wide range of solution chemistries has been conducted (68). While the largest titania aggregate sizes are encountered at $\mathrm{pH}$ values closest to the $\mathrm{pH}_{\mathrm{pp}}$, these aggregates have 
been found to remain highly mobile. QCM deposition behavior of $n \mathrm{TiO}_{2}$ onto silica was found to be in good qualitative agreement with DLVO theory (66). Working in a similar system with QD suspensions, heightened deposition is observed in the presence of divalent cations versus monovalent cations, with QD aggregation resulting in lowered deposition rate at higher ionic strength (85).

Although it is not straightforward to compare the results of deposition studies conducted with various engineered nanomaterials under dissimilar experimental conditions (e.g., solution chemistry, collector surfaces, and nanoparticle preparation methods), Figure 2 presents a direct comparison of data obtained in different laboratories with a wide range of nanomaterials. The deposition stability curves in Figure 2 show that nanoparticles of very dissimilar composition (e.g., $n \mathrm{~B}$ and sulfate modified latex (SML)) can exhibit comparable deposition behavior. It is interesting to note that much of the experimental data falls in a given region of the plot and exhibits an increase in $\alpha_{\mathrm{d}}$ with increasing ionic strength. SWNTs (purple diamonds) generally experience greater retention in granular media, likely due to the influence of physical straining as discussed above. The black symbols in Fig. 2 represent data obtained using $n Z V I$ with differing surface modifications. These nanomaterials generally exhibit greater stability as a result of steric stabilization imparted by their polymer coatings. Similar to the conclusion drawn from inspection of Fig. 1, the data in Fig. 2 shows that the deposition of engineered nanomaterials also generally follows the classical behavior of colloids, with the exception of those particles that experience additional mechanisms such as steric stabilization or physical straining.

\section{Challenges in Quantifying Nanoparticle Deposition and Aggregation in the Environment}

Recent reviews and viewpoints have touched upon the challenges associated with characterizing nanomaterials in environmental settings. Many of these same challenges apply when considering nanoparticle aggregation and deposition in natural settings, given that in-depth particle characterization is required to fully understand particle mobility. Generally, difficulties arise due to a lack of analytical tools capable of characterizing and quantifying particles in complex environmental matrices. As a result, most deposition and aggregation studies have been conducted with simplified model laboratory systems. However, while providing important insights, particle behavior in model 
laboratory systems might not be representative of that observed in far more complex natural environments.

Nanoparticle transport, persistence, and bioavailability in the environment are essential aspects to consider in assessing and managing risks ( 7 ). Factors such as microorganisms, naturally-occurring colloids and organic matter, biomacromolecules (e.g., proteins and polysaccharides), sunlight, and oxidants/reductants will complicate particle behavior in natural environments $(1,2)$, likely resulting in deviations from laboratory-scale experimental observations. Nanoparticles undergoing aggregation will sediment, thus becoming far less mobile. These aggregates may be ingested by organisms, potentially making their way into food chains (2). The impact that biota such as biofilms and invertebrates have on particle behavior remains unclear and must also be considered in natural settings (1).

Along with engineered nanoparticles, naturally occurring nanoparticles can also be found in the environment (7). Unintentional or incidental nanoparticles are a third source, and can originate from combustion, weathering, and oxidation processes among others $(6,7)$. When dealing with engineered, natural, and incidental nanoparticles simultaneously, establishing the source for any given particle is complicated (139). Additionally, background levels of certain elements, such as iron, in the environment may be significant (1). As a result, differentiating between the background elements and the engineered nanoparticles becomes a necessary and complicated task.

A majority of the aggregation and deposition studies conducted thus far have involved bare, non-functionalized nanomaterials. However, nanoparticles released into the environment may be either matrix bound or functionalized, thus altering their behavior (5). In the aim of understanding and predicting nanoparticle fate in aqueous environments, an in-depth characterization of particle surfaces following functionalization is necessary. A review describing the experimental methods available for analyzing nanoparticle surface chemistry and structure following intentional surface modification has been compiled (140). Regardless of prior characterization, additional particle modifications and chemical transformations can also occur upon release into the environment (2). For example, particles may undergo redox reactions or become coated with organic matter ( 7 ). Organic matter alters surface charge, thus affecting particle stability and aggregate size. Bridging due to the 
adsorption of certain polymers onto particle surfaces can result in heightened aggregation. Both chemical and biological processes may result in inadvertent surface functionalization (G). On the other hand, such processes may wear down or alter existing surface functionality and particle coatings.

Environmental measurements are complex, with trace amounts of particles dispersed in a highly heterogeneous matrix. Currently, environmental nanomaterial concentrations, along with particle distribution and physicochemical data in natural settings, remain largely unavailable $(1,141)$. Analytical tools enabling the quantification of nanomaterials in multifaceted environmental matrices must be developed in order to better understand particle behavior. While techniques capable of identifying nanoparticles in sediments are available, they are incapable of quantifying the particles (๑). Quantification will be further hindered by spatial and temporal variations in concentration (1). In the absence of appropriate tools, recent studies have modeled predicted environmental concentrations as a substitute $(4,141)$.

Along with information regarding particle concentration, additional properties such as the size distribution must be determined to fully comprehend the aggregation and deposition processes. A recent review by Tiede et al. (142) provides a detailed summary of the analytical tools currently available for nanoparticle characterization. While various characterization techniques can be employed, only a handful can deal with multifaceted environmental samples. Such samples present an assortment of elemental constituents and can potentially include multiple nanoparticle types. To further complicate matters, particles will likely be polydispersed in natural settings, making particle size determination more difficult. The nanoparticles encountered may also be in the dissolved, colloidal and particulate phases $(1,142)$.

Two key questions about nanoparticle aggregation and deposition were pointed out in the Introduction section of the manuscript; namely, "How do specific particle and environmental properties affect deposition and aggregation?", and "Are the current approaches and models used in quantifying colloidal interactions and transport applicable to nanomaterials?". This critical review begins to address these questions; however, it is evident that our current understanding of nanoparticle deposition and aggregation precludes a definitive unified answer. Although generalizations on the role of specific particle and environmental properties cannot yet be established, a comprehensive analysis of published 
studies (Figures 1 and 2, and Tables 2 and 3) reveals that traditional DLVO theory can generally semiquantitatively describe nanoparticle aggregation and deposition behavior. However, certain particle properties can lead to non-DLVO behavior; for instance, surface modifications such as polymer or surfactant coatings give rise to steric stabilization resulting in decreased nanomaterial deposition or aggregation. Moreover, unusual particle shapes, such as in the case of CNTs, can give rise to additional capture mechanisms (e.g., straining) which result in unpredicted nanomaterial transport patterns. Most common experimental and theoretical approaches used for evaluation of nanomaterial deposition and aggregation are applicable for spherical particles; however, we have noted above certain limitations for non-spherical or very small particles. 


\section{Acknowledgements}

This research was supported by NSERC, McGill Engineering Doctoral Awards to ARP and IQP, the Canada Research Chairs Program, and the U.S. NSF under Research Grants CBET-0828795 and BES 0646247. 


\section{Nomenclature}

\section{Symbols}

A

$A_{\text {s }}$

$a_{c}$

$a_{\mathrm{h}}$

$a_{\mathrm{i}}, a_{\mathrm{p}}$

b

C

$C_{0}$

$C / C_{0}$

$C(x, t)$

D

$D_{\infty}$

$d_{c}$

$e$

$F_{\text {ST }}$

f

$g_{1}(H)$

H

h

$h_{\mathrm{c}}$

$K_{\mathrm{F}}$

$k_{\mathrm{B}}$

$k_{\mathrm{d}}$

$k_{\mathrm{ij}}$
Hamaker constant

porosity-dependent parameter of Happel's model, $A_{s}=2\left(1-P^{5}\right) / w$ collector radius

hydrodynamic radius

particle radius, $i=1,2$

fluid envelope radius in Happel's model, $b=a_{c}(1-\varepsilon)^{1 / 3}$

effluent particle concentration

influent particle concentration

normalized effluent particle concentration

particle concentration at depth $x$ and time $t$

hydrodynamic dispersion coefficient

diffusion coefficient in an infinite medium, $D_{\infty}=k_{B} T /\left(6 \pi \mu a_{p}\right)$

average collector grain diameter

electron charge, $1.602 \times 10^{-19} \mathrm{C}$

steric force

resonance frequency

universal hydrodynamic function, $g_{1}(H)=1 / f_{1}(H)$

dimensionless separation distance, $H=h / a_{\mathrm{p}}$

surface-to-surface separation distance

height of parallel-plate chamber

pseudo-first order rate constant

Boltzmann constant, $1.3805 \times 10^{-23} \mathrm{~J} / \mathrm{K}$

particle deposition rate coefficient

perikinetic aggregation rate constant between dissimilar-size particles 


\begin{tabular}{|c|c|}
\hline$k_{\mathrm{ii}}$ & perikinetic aggregation rate constant between equal-size particles \\
\hline$L$ & bed depth \\
\hline$l$ & film thickness \\
\hline$M$ & magnetization \\
\hline$m$ & mass \\
\hline$N_{0}$ & initial particle number concentration \\
\hline$n_{0}$ & ratio of total injected particles to volumetric flow rate \\
\hline$P$ & ratio of $a_{c} l b, P=(1-\varepsilon)^{-1 / 3}$ \\
\hline $\mathrm{Pe}$ & Péclet number, $P e=2 U a_{p} / D_{\infty}$ \\
\hline$r$ & radial coordinate \\
\hline$r_{\mathrm{d}}$ & particle deposition rate \\
\hline$S(\beta)$ & $\beta$ function defined by Spielman and Friedlander (122) \\
\hline$s$ & distance between polymer chains on a surface \\
\hline$t$ & time \\
\hline$T$ & absolute temperature \\
\hline$U$ & approach (Darcy) velocity \\
\hline$v$ & fluid interstitial velocity, $v=U / \varepsilon$ \\
\hline$V_{\mathrm{EDL}}$ & electrical double-layer interaction energy \\
\hline$V_{\mathrm{M}}$ & magnetic interaction energy \\
\hline$V_{\text {ST }}$ & steric interaction energy \\
\hline$V_{\mathrm{VDW}}$ & van der Waals interaction energy \\
\hline$V_{\max }$ & energy barrier height \\
\hline$V_{\mathrm{T}}$ & total interaction energy \\
\hline$w$ & porosity-dependent parameter, $w=2-3 P+3 P^{5}-2 P^{6}$ \\
\hline$W$ & stability ratio \\
\hline$x$ & distance from inlet (along flow) \\
\hline$y$ & boundary layer coordinate perpendicular to collector \\
\hline 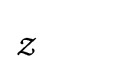 & counterion valence \\
\hline
\end{tabular}




\section{Greek Symbols}

\begin{tabular}{|c|c|c|}
\hline$\alpha_{\mathrm{a}}$ & aggregation attachment efficiency & \\
\hline$\alpha_{\mathrm{d}}$ & deposition attachment efficiency & \\
\hline$\Gamma_{\mathrm{i}}$ & dimensionless surface potential for particle or collector, $\Gamma_{i}=\tanh$ & $\frac{z e \psi_{i}}{4 k_{B} T}$ \\
\hline$\delta_{\mathrm{D}}$ & diffusion boundary layer thickness & \\
\hline$\delta_{\mathrm{F}}$ & electrical double-layer thickness & \\
\hline$\varepsilon$ & porosity & \\
\hline$\varepsilon_{0}$ & dielectric permittivity in vacuum, $8.85 \times 10^{-12} \mathrm{~F} / \mathrm{m}$ & \\
\hline$\varepsilon_{\mathrm{r}}$ & relative dielectric permittivity of solution & \\
\hline$\zeta$ & zeta potential & \\
\hline$\eta$ & single-collector removal efficiency & \\
\hline$\eta_{0}$ & overall single-collector contact efficiency & \\
\hline$\eta_{\mathrm{D}}$ & single-collector contact efficiency for transport by diffusion & \\
\hline$\eta_{\mathrm{G}}$ & single-collector contact efficiency for transport by gravity & \\
\hline$\eta_{\mathrm{I}}$ & single-collector contact efficiency for transport by interception & \\
\hline$\kappa$ & inverse Debye length & \\
\hline$\lambda$ & characteristic wavelength & \\
\hline$\mu$ & absolute viscosity of fluid & \\
\hline$\psi$ & surface potential & \\
\hline
\end{tabular}




\section{Literature Cited}

1. Klaine, S. J.; Alvarez, P. J. J.; Batley, G. E.; Fernandes, T. F.; Handy, R. D.; Lyon, D. Y.; Mahendra, S.; McLaughlin, M. J.; Lead, J. R., Nanomaterials in the environment: Behavior, fate, bioavailability, and effects. Environ. Toxicol. Chem. 2008, 27, (9), 1825-1851.

2. Wiesner, M. R.; Bottero, J.-Y., Environmental Nanotechnology. The McGraw-Hill Companies: New York, 2007; p 540 .

3. Maynard, A. D.; Aitken, R. J.; Butz, T.; Colvin, V.; Donaldson, K.; Oberdörster, G.; Philbert, M. A.; Ryan, J.; Seaton, A.; Stone, V.; Tinkle, S. S.; Tran, L.; Walker, N. J.; Warheit, D. B., Safe handling of nanotechnology. Nature 2006, 444, (7117), 267-269.

4. Mueller, N. C.; Nowack, B., Exposure modeling of engineered nanoparticles in the environment. Environ. Sci. Technol. 2008, 42, (12), 4447-4453.

5. Nowack, B.; Bucheli, T. D., Occurrence, behavior and effects of nanoparticles in the environment. Environmental Pollution 2007, 150, (1), 5-22.

6. Farré, M.; Gajda-Schrantz, K.; Kantiani, L.; Barceló, D., Ecotoxicity and analysis of nanomaterials in the aquatic environment. Analytical and Bioanalytical Chemistry 2009, 393, (1), 81-95.

7. Wiesner, M. R.; Lowry, G. V.; Jones, K. L.; Hochella, Jr.; DiGiulio, R. T.; Casman, E.; Bernhardt, E. S., Decreasing uncertainties in assessing environmental exposure, risk, and ecological implications of nanomaterials. Environ. Sci. Technol. 2009, 43, (17), 6458-6462.

8. Elimelech, M., Gregory, J., Jia, X., Williams, R. A., Particle Deposition and Aggregation: Measurement, Modeling, and Simulation Butterworth-Heinemann, Oxford 1995.

9. Tufenkji, N.; Elimelech, M., Correlation equation for predicting single-collector efficiency in physicochemical filtration in saturated porous media. Environ. Sci. Technol. 2004, 38, (2), 529-536.

10. Yao, K. M.; Habibian, M. T.; O'Melia, C. R., Water and waste water filtration: Concepts and applications. Environ. Sci. Technol. 1971, 5, (11), 1105-1112.

11. Auffan, M.; Rose, J.; Bottero, J.-Y.; Lowry, G. V.; Jolivet, J.-P.; Wiesner, M. R., Towards a definition of inorganic nanoparticles from an environmental, health and safety perspective. Nature Nanotechnology 2009, 4, 634-641.

12. Anderson, R.; Barron, A. R., Reaction of hydroxyfullerene with metal salts: A route to remediation and immobilization. J. American Chemical Soc. 2005, 127, (30), 10458-10459.

13. Andrievsky, G. V.; Klochkov, V. K.; Karyakina, E. L.; McHedlov-Petrossyan, N. O., Studies of aqueous colloidal solutions of fullerene $\mathrm{C}_{60}$ by electron microscopy. Chemical Physics Letters 1999, 300, (3-4), 392-396.

14. Bouchard, D.; Ma, X.; Issacson, C., Colloidal properties of aqueous fullerenes: Isoelectric points and aggregation kinetics of C-60 and C-60 derivatives. Environ. Sci. Technol. 2009, 43, (17), 6597-6603.

15. Brant, J.; Lecoanet, H.; Wiesner, M. R., Aggregation and deposition characteristics of fullerene nanoparticles in aqueous systems. J. Nanoparticle Res. 2005, 7, (4-5), 545-553.

16. Chen, K. L., Elimelech, M., Aggregation and deposition kinetics of fullerene (C-60) nanoparticles. Langmuir 2006, 22, 10994-11001.

17. Chen, K. L., Elimelech, M., Influence of humic acid on the aggregation kinetics of fullerene (C-60) nanoparticles in monovalent and divalent electrolyte solutions. J. Colloid Interface Sci. 2007, 309, (1), 126-134.

18. Chen, K. L., Elimelech, M., Relating colloidal stability of fullerene (C60) nanoparticles to nanoparticle charge and electrokinetic properties. Environ. Sci. Technol. 2009, 43, 7270-7276.

19. Deguchi, S.; Alargova, R. G.; Tsujii, K., Stable dispersions of fullerenes, C60 and C70, in water. Preparation and characterization. Langmuir 2001, 17, (19), 6013-6017.

20. Liu, X., Wazne, M., Christodoulatos, C., Jasinkiewicz, K.L., Aggregation and deposition behavior of boron nanoparticles in porous media. J. Colloid Interface Sci. 2009, 330, 90-96.

21. Ma, X.; Bouchard, D., Formation of aqueous suspensions of fullerenes. Environ. Sci. Technol. 2009, 43, (2), 330336.

22. Mchedlov-Petrossyan, N. O., Klochkov, V.K., Andrievsky,G.V., Colloidal dispersions of fullerene C-60 in water: some properties and regularities of coagulation by electrolytes. Journal of Chemical Society- Faraday Transections 1997, 93, $4343-4346$. 
23. Smith, B., Wepasnick, K., Schrote, K. E., Bertele, A. H., Ball, W. P., O'Melia, C., Fairbrother, D. H., Colloidal properties of aqueous suspensions of acid-treated, multi-walled carbon nanotubes. Environ. Sci. Technol. 2009, 43, (3), 819-825.

24. Smith, B.; Wepasnick, K.; Schrote, K. E.; Cho, H. H.; Ball, W. P.; Fairbrother, D. H., Influence of surface oxides on the colloidal stability of multi-walled carbon nanotubes: A structure-property relationship. Langmuir 2009, 25, (17), 9767-9776.

25. Wang, Y.; Li, Y.; Pennell, K. D., Influence of electrolyte species and concentration on the aggregation and transport of fullerene nanoparticles in quartz sands. Environmental Toxicology and Chemistry 2008, 27, (9), 1860-1867.

26. Dagtepe, P.; Chikan, V., Effect of $\mathrm{Cd} / \mathrm{Te}$ ratio on the formation of $\mathrm{CdTe}$ magic-sized quantum dots during aggregation. J. Phys. Chem. A 2008, 112, (39), 9304-9311.

27. Dong, C. Q.; Qian, H. H.; Fang, N. H.; Ren, J. C., On-line investigation of laser-induced aggregation and photoactivation of CdTe quantum dots by fluorescence correlation spectroscopy. J. Phys. Chem. C 2007, 111, (22), 79187923.

28. Hyung, H., Fortner, J. D., Hughes, J. B., Kim, J. H., Natural organic matter stabilizes carbon nanotubes in the aqueous phase. Environ. Sci. Technol. 2007, 41, (1), 179-184.

29. Kennedy, A. J., Hull, M.S., Steevens, J.A. et al., Factors influencing the partitioning and toxicity of nanotubes in the aquatic environment Environmental Toxicology and Chemistry 2008, 27, 1932-1941.

30. Lin, D., Xing, B., Tannic acid adsorption and its role for stabilizing carbon nanotube suspensions. Environ. Sci. Technol. 2008, 42, 5917-5923.

31. Lin, D. H.; Liu, N.; Yang, K.; Zhu, L. Z.; Xu, Y.; Xing, B. S., The effect of ionic strength and pH on the stability of tannic acid-facilitated carbon nanotube suspensions. Carbon 2009, 47, (12), 2875-2882.

32. Moskovits, M.; Vlckova, B., Adsorbate-induced silver nanoparticle aggregation kinetics. J. Phys. Chem. B 2005, 109, (31), 14755-14758.

33. Niyogi, S., Boukhalfa, S., Chikkannanavar, S.B., McDonald, T.J., Heben, M.J., Doorn, S.K., Selective aggregation of single-walled carbon nanotubes via salt addition. Journal of Americal Chemical Society 2007, 129, 18981899 .

34. Saleh, N. B.; Pfefferle, L. D.; Elimelech, M., Aggregation kinetics of multiwalled carbon nanotubes in aquatic systems: Measurements and environmental implications. Environ. Sci. Technol. 2008, 42, (21), 7963-7969.

35. Samoilova, N.; Kurskaya, E.; Krayukhina, M.; Askadsky, A.; Yamskov, I., Copolymers of maleic acid and their amphiphilic derivatives as stabilizers of silver nanoparticles. J. Phys. Chem. B 2009, 113, (11), 3395-3403.

36. Sano, M., Okamura, J., Shinkai, S., Colloidal nature of single-walled carbon nanotubes in electrolyte solution: The Schulze-Hardy rule. Langmuir 2001, 17, 7172-7173.

37. Sano, M., Kamino, A., Okamura, J., Shinkai, S., Self-organization of PEO-graft-single-walled carbon nanotubes in solutions and Langmuir-Blodgett films. Langmuir 2001, 17, 5125-5128.

38. Shieh, Y. T.; Liu, G. L.; Wu, H. H.; Lee, C. C., Effects of polarity and $\mathrm{pH}$ on the solubility of acid-treated carbon nanotubes in different media. Carbon 2007, 45, (9), 1880-1890.

39. Trinh, L. T. T.; Kjøniksen, A. L.; Zhu, K.; Knudsen, K. D.; Volden, S.; Glomm, W. R.; Nyström, B., Slow saltinduced aggregation of citrate-covered silver particles in aqueous solutions of cellulose derivatives. Colloid and Polymer Science 2009, 287, (12), 1391-1404.

40. Vaisman, L.; Marom, G.; Wagner, H. D., Dispersions of surface-modified carbon nanotubes in water-soluble and water-insoluble polymers. Advanced Functional Materials 2006, 16, (3), 357-363.

41. Zhang, Y., Chen, Y., Westerhoff, P., Crittenden, J.C., Stability and removal of water soluble CdTe quantum dots in water. Environ. Sci. Technol. 2008, 42, 321-325.

42. Zhang, Y.; Mi, L.; Wang, P. N.; Ma, J.; Chen, J. Y., pH-dependent aggregation and photoluminescence behavior of thiol-capped CdTe quantum dots in aqueous solutions. Journal of Luminescence 2008, 128, (12), 1948-1951.

43. Domingos, R. F.; Tufenkji, N.; Wilkinson, K. J., Aggregation of titanium dioxide nanoparticles: role of fulvic acid. Environ. Sci. Technol. 2009.

44. Fang, J., Shan, X., Wen, B., Lin, J., Owens, G., Stability of titania nanoparticles in soil suspensions and transport in saturated homogenous soil columns. Environmental Pollution 2009. 
45. French, R. A.; Jacobson, A. R.; Kim, B.; Isley, S. L.; Penn, L.; Baveye, P. C., Influence of ionic strength, pH, and cation valence on aggregation kinetics of titanium dioxide nanoparticles. Environ. Sci. Technol. 2009, 43, (5), 1354-1359.

46. He, F., Zhao, D., Manipulating the size and dispersibility of zerovalent iron nanoparticles by use of carboxymethyl cellulose stabilizers. Environ. Sci. Technol. 2007, 41, 6216-6221.

47. Johnson, R. L.; Johnson, G. O.; Nurmi, J. T.; Tratnyek, P. G., Natural organic matter enhanced mobility of nano zerovalent iron. Environ. Sci. Technol. 2009, 43, (14), 5455-5460.

48. Liu, Y.; Liu, C. Y.; Chen, L. B.; Zhang, Z. Y., Adsorption of cations onto the surfaces of silver nanoparticles. J. Colloid Interface Sci. 2003, 257, (2), 188-194.

49. Pavlova-Verevkina, O. B.; Ozerina, L. A.; Politova, E. D.; Surin, N. M.; Ozerin, A. N., Effect of electrolytes on the slow aggregation of $\mathrm{TiO}_{2}$ nanocrystals. Colloid Journal 2009, 71, (4), 529-533.

50. Pettibone, J. M., Cwiertny, D.M., Scherer, M. et al., Adsorption of organic acids on TiO2 nanoparticles: Effects of $\mathrm{pH}$, nanoparticle size, and nanoparticle aggregation Langmuir 2008, 24, 6659-6667.

51. Phenrat, T., Saleh, N., Sirk, K. Tilton, R. Lowry, G.V., Aggregation and sedimentation of aqueous nanoiron dispersions. Environ. Sci. Technol. 2007, 284-290.

52. Phenrat, T., Saleh, N., Sirk, K., Kim, H.-J., Tilton, R. D., Lowry, G. V., Stabilization of aqueous nanoscale zerovalent iron dispersions by anionic polyelectrolytes: Adsorbed anionic polyelectrolyte layer properties and their effect on aggregation and sedimentation. J. Nanoparticle Res. 2008, 10, 795-814.

53. Sun, Y. P.; Li, X. Q.; Zhang, W. X.; Wang, H. P., A method for the preparation of stable dispersion of zerovalent iron nanoparticles. Colloids And Surfaces A: Physicochemical and Engineering Aspects 2007, 308, 60-66.

54. Tiraferri, A., Chen, K. L., Sethi, R., Elimelech, M., Reduced aggregation and sedimentation of zero-valent iron nanoparticles in the presence of guar gum. J. Colloid Interface Sci. 2008, 324, (1-2), 71-79.

55. Tkachenko, N. H., Yaremko, Z.M., Bellmann, C., Effect of 1-1-charged ions on aggregative stability and electrical surface properties of aqueous suspensions of titanium dioxide. Colloids And Surfaces A: Physicochemical and Engineering Aspects 2006, 79, 10-19.

56. Tseng, W. J.; Lin, K. C., Rheology and colloidal structure of aqueous TiO2 nanoparticle suspensions. Materials Science and Engineering A 2003, 355, (1-2), 186-192.

57. Chen, K. L.; Elimelech, M., Interaction of fullerene (C60) nanoparticles with humic acid and alginate coated silica surfaces: Measurements, mechanisms, and environmental implications. Environ. Sci. Technol. 2008, 42, (20), 76077614 .

58. Chen, L.; Sabatini, D. A.; Kibbey, T. C. G., Role of the air-water interface in the retention of TiO2 nanoparticles in porous media during primary drainage. Environ. Sci. Technol. 2008, 42, (6), 1916-1921.

59. Cheng, X.; Kan, A. T.; Tomson, M. B., Study of C60 transport in porous media and the effect of sorbed C60 on naphthalene transport. J. Mater. Res. 2005, 20, (12), 3244-3254.

60. Choy, C. C.; Wazne, M.; Meng, X., Application of an empirical transport model to simulate retention of nanocrystalline titanium dioxide in sand columns. Chemosphere 2008, 71, (9), 1794-1801.

61. Doshi, R.; Braida, W.; Christodoulatos, C.; Wazne, M.; O'Connor, G., Nano-aluminum: Transport through sand columns and environmental effects on plants and soil communities. Environ. Res. 2008, 106, (3), 296-303.

62. Elimelech, M.; O'Melia, C. R., Effect of particle size on collision efficiency in the deposition of brownian particles with electrostatic energy barriers. Langmuir 1990, 6, (6), 1153-1163.

63. Elimelech, M.; O'Melia, C. R., Kinetics of deposition of colloidal particles in porous media. Environ. Sci. Technol. 1990, 24, (10), 1528-1536.

64. Elliott, D. W.; Zhang, W. X., Field assessment of nanoscale bimetallic particles for groundwater treatment. Environ. Sci. Technol. 2001, 35, (24), 4922-4926.

65. Espinasse, B.; Hotze, E. M.; Wiesner, M. R., Transport and retention of colloidal aggregates of C60 in porous media: Effects of organic macromolecules, ionic composition, and preparation method. Environ. Sci. Technol. 2007, 41, (21), 7396-7402.

66. Fatisson, J.; Domingos, R. F.; Wilkinson, K. J.; Tufenkji, N., Deposition of TiO2 nanoparticles onto silica measured using quartz crystal microbalance with dissipation monitoring. Langmuir 2009, 25, (11), 6062-6069.

67. Franchi, A.; O'Melia, C. R., Effects of natural organic matter and solution chemistry on the deposition and reentrainment of colloids in porous media. Environ. Sci. Technol. 2003, 37, (6), 1122-1129. 
68. Guzman, K. A. D., Finnegan, M.P., Banfield, J.F., Influence of surface potential on aggregation and transport of titania nanoparticles Environ. Sci. Technol. 2006, 40, 7688-7693.

69. Hahn, M. W.; Abadzic, D.; O'Melia, C. R., Aquasols: On the role of secondary minima. Environ. Sci. Technol. 2004, 38, (22), 5915-5924.

70. He, F.; Zhao, D.; Liu, J.; Roberts, C. B., Stabilization of Fe - Pd nanoparticles with sodium carboxymethyl cellulose for enhanced transport and dechlorination of trichloroethylene in soil and groundwater. Industrial and Engineering Chemistry Research 2007, 46, (1), 29-34.

71. Huber, N.; Baumann, T.; Niessner, R., Assessment of colloid filtration in natural porous media by filtration theory. Environ. Sci. Technol. 2000, 34, (17), 3774-3779.

72. Hydutsky, B. W.; Mack, E. J.; Beckerman, B. B.; Skluzacek, J. M.; Mallouk, T. E., Optimization of nano- and microiron transport through sand columns using polyelectrolyte mixtures. Environ. Sci. Technol. 2007, 41, (18), 64186424.

73. Jaisi, D. P., Saleh, N., Blake, R., Elimelech, M., Transport of single-walled carbon nanotubes in porous media: Filtration mechanisms and reversibility. Environ. Sci. Technol. 2008, 42, 8317-8323.

74. Jaisi, D. P.; Elimelech, M., Single-walled carbon nanotubes exhibit limited transport in soil columns. Environ. Sci. Technol. 2009, 43, (24), 9161-9166.

75. Jeong, S. W.; Kim, S. D., Aggregation and transport of copper oxide nanoparticles in porous media. J. Environ. Monitoring 2009, 11, (9), 1595-1600.

76. Kanel, S. R.; Goswami, R. R.; Clement, T. P.; Barnett, M. O.; Zhao, D., Two dimensional transport characteristics of surface stabilized zero-valent iron nanoparticles in porous media. Environ. Sci. Technol. 2008, 42, (3), 896-900.

77. Kanel, S. R.; Nepal, D.; Manning, B.; Choi, H., Transport of surface-modified iron nanoparticle in porous media and application to arsenic(III) remediation. J. Nanoparticle Res. 2007, 9, (5), 725-735.

78. Lecoanet, H. F.; Bottero, J. Y.; Wiesner, M. R., Laboratory assessment of the mobility of nanomaterials in porous media. Environ. Sci. Technol. 2004, 38, (19), 5164-5169.

79. Lecoanet, H. F.; Wiesner, M. R., Velocity effects on fullerene and oxide nanoparticle deposition in porous media. Environ. Sci. Technol. 2004, 38, (16), 4377-4382.

80. Li, Y., Wang, Y., Pennell, K.D., Abriola, L.M., Investigation of the transport and deposition of fullerene $\left(\mathrm{C}_{60}\right)$ nanoparticles in quartz sands under varying flow conditions. Environ. Sci. Technol. 2008, 42, 7174-7180

81. Limbach, L. K.; Bereiter, R.; Müller, E.; Krebs, R.; Gälli, R.; Stark, W. J., Removal of oxide nanoparticles in a model wastewater treatment plant: Influence of agglomeration and surfactants on clearing efficiency. Environ. Sci. Technol. 2008, 42, 5828-5833.

82. Mattigod, S. V.; Fryxell, G. E.; Alford, K.; Gilmore, T.; Parker, K.; Serne, J.; Engelhard, M., Functionalized $\mathrm{TiO} 2$ nanoparticles for use for in situ anion immobilization. Environ. Sci. Technol. 2005, 39, (18), 7306-7310.

83. Pelley, A. J., Tufenkji, N., Effect of particle size and natural organic matter on the migration of nano- and microscale latex particles in saturated porous media J. Colloid Interface Sci. 2008, 321, (74-83).

84. Phenrat, T.; Kim, H. J.; Fagerlund, F.; Illangasekare, T.; Tilton, R. D.; Lowry, G. V., Particle size distribution, concentration, and magnetic attraction affect transport of polymer-modified $\mathrm{Fe} 0$ nanoparticles in sand columns. Environ. Sci. Technol. 2009, 43, (13), 5079-5085.

85. Quevedo, I. R.; Tufenkji, N., Influence of solution chemistry on the deposition and detachment kinetics of a CdTe quantum dot examined using a quartz crystal microbalance. Environ. Sci. Technol. 2009, 43, (9), 3176-3182.

86. Saleh, N.; Kim, H. J.; Phenrat, T.; Matyjaszewski, K.; Tilton, R. D.; Lowry, G. V., Ionic strength and composition affect the mobility of surface-modified $\mathrm{Fe} 0$ nanoparticles in water-saturated sand columns. Environ. Sci. Technol. 2008, 42, (9), 3349-3355.

87. Schrick, B.; Hydutsky, B. W.; Blough, J. L.; Mallouk, T. E., Delivery vehicles for zerovalent metal nanoparticles in soil and groundwater. Chemistry of Materials 2004, 16, (11), 2187-2193.

88. Shani, C.; Weisbrod, N.; Yakirevich, A., Colloid transport through saturated sand columns: Influence of physical and chemical surface properties on deposition. Colloids and Surfaces A: Physicochemical and Engineering Aspects 2008, 316 , (1-3), 142-150. 
89. Shen, C.; Huang, Y.; Li, B.; Jin, Y., Effects of solution chemistry on straining of colloids in porous media under unfavorable conditions. Water Resources Research 2008, 44, (5).

90. Sung, H. J.; Al-Abed, S. R.; Luxton, T., Influence of carboxymethyl cellulose for the transport of titanium dioxide nanoparticles in clean silica and mineral-coated sands. Environ. Sci. Technol. 2009, 43, (13), 4954-4959.

91. Tufenkji, N.; Elimelech, M., Breakdown of colloid filtration theory: Role of the secondary energy minimum and surface charge heterogeneities. Langmuir 2005, 21, (3), 841-852.

92. Wang, P., Shi, Q.H., Liang, H.J., et al., Enhanced environmental mobility of carbon nanotubes in the presence of humic acid and their removal from aqueous solution Small 2008, 12, 2166-2170.

93. Wang, Y.; Li, Y.; Fortner, J. D.; Hughes, J. B.; Abriola, L. M.; Pennell, K. D., Transport and retention of nanoscale C60 aggregates in water-saturated porous media. Environ. Sci. Technol. 2008, 42, (10), 3588-3594.

94. Zhan, J.; Zheng, T.; Piringer, G.; Day, C.; McPherson, G. L.; Lu, Y.; Papadopoulos, K.; John, V. T., Transport characteristics of nanoscale functional zerovalent iron/silica composites for in situ remediation of trichloroethylene. Environ. Sci. Technol. 2008, 42, (23), 8871-8876.

95. Zhuang, J.; Qi, J.; Jin, Y., Retention and transport of amphiphilic colloids under unsaturated flow conditions: Effect of particle size and surface property. Environ. Sci. Technol. 2005, 39, (20), 7853-7859.

96. Xueying, L.; O'Carroll, D. M.; Petersen, E. J.; Qingguo, H.; Anderson, C. L., Mobility of multiwalled carbon nanotubes in porous media. Environ. Sci. Technol. 2009, 43, (21), 8153-8158.

97. Esquivel, E. V.; Murr, L. E., A TEM analysis of nanoparticulates in a polar ice core. Materials Characterization 2004, 52, (1), 15-25.

98. Verwey, E. J. W.; Overbeek, J. T. G., Theory of the Stability of Lyophobic Colloids. Elsevier: Amsterdam, 1948.

99. Derjaguin, B. V.; Landau, L. D., Theory of stability of strongly charged lyophobic sols and the adhesion of strongly charged particles in solutions of electrolytes. Acta Physicochim. URSS 1941, 14, 733-762.

100. Hamaker, H. C., The London-van der Waals attraction between spherical particles. Physica 1937, 4, (10), 1058-

1072 .

101. Bergström, L., Hamaker constants of inorganic materials. Advances in Colloid and Interface Science 1997, 70, 125-169.

102. Ross, S.; Morrison, I. D., Colloidal Systems and Interfaces. John Wiley \& Sons, Inc.: New York, 1988.

103. Gregory, J., Interaction of unequal double layers at constant charge. J. Colloid Interface Sci. 1975, 51, (1), 44-51.

104. Alexander, S., Adsorption of chain molecules with a polar head. A scaling description. J Phys (Paris) 1977, 38, (8), 983-987.

105. de Gennes, P. G., Dry spreading of a liquid on a random surface. Comptes rendus des seances de l'Academie des sciences. Serie 2, Mecanique, Physique, Chimie, Sciences de la Terre, Sciences de l'univers 1985, 300, (4), 129-132.

106. de Vicente, J.; Delgado, A. V.; Plaza, R. C.; Durán, J. D. G.; González-Caballero, F., Stability of cobalt ferrite colloidal particles. Effect of $\mathrm{pH}$ and applied magnetic fields. Langmuir 2000, 16, (21), 7954-7961.

107. Healy, T. W.; Homola, A.; James, R. O.; Hunter, R. J., Coagulation of amphoteric latex colloids - reversibility and specific ion effects. Faraday Discussions 1978, 65, 156-163.

108. Chen, J. Y.; Ko, C. H.; Bhattacharjee, S.; Elimelech, M., Role of spatial distribution of porous medium surface charge heterogeneity in colloid transport. Colloids and Surfaces A: Physicochemical and Engineering Aspects 2001, 191, (12), 3-15.

109. Song, L.; Johnson, P. R.; Elimelech, M., Kinetics of colloid deposition onto heterogeneously charged surfaces in porous media. Environ. Sci. Technol. 1994, 28, (6), 1164-1171.

110. Chen, J. Y.; Klemic, J. F.; Elimelech, M., Micropatterning microscopic charge heterogeneity on flat surfaces for studying the interaction between colloidal particles and heterogeneously charged surfaces. Nano Letters 2002, 2, (4), 393396.

111. Hahn, M. W.; O'Melia, C. R., Deposition and reentrainment of Brownian particles in porous media under unfavorable chemical conditions: Some concepts and applications. Environ. Sci. Technol. 2004, 38, (1), 210-220.

112. Bhattacharjee, S.; Elimelech, M., Surface element integration: A novel technique for evaluation of DLVO interaction between a particle and a flat plate. J. Colloid Interface Sci. 1997, 193, (2), 273-285.

113. Bhattacharjee, S.; Chen, J. Y.; Elimelech, M., DLVO Interaction between Spheroidal Particles and a Flat Surface. Colloids and Surfaces $A$ 2000, 165, 143-156. 
114. Fuchs, N., Uber die stabilitat und aufladung der aerosole. Z. Physik 1934, 89, 736-743.

115. Ottewill, R. H.; Shaw, J. N., Stability of monodisperse polystyrene latex dispersions of various sizes. Discuss. Faraday Soc. 1966, 42, 154-163.

116. Marmur, A., A kinetic theory approach to primary and secondary minimum coagulations and their combination J. Colloid Interface Sci. 1979, 72, (1), 41-48.

117. Ofoli, R. Y.; Prieve, D. C., Small-angle Rayleigh scattering by relatively large latex particles. Langmuir 1997, 13, (18), 4837-4842.

118. Thompson, N. L., Fluorescence correlation spectroscopy. In Topics in Fluorescence Spectroscopy, Techniques, Lakowicz, J. R., Ed. Plenum Press New York, 1991; Vol. 1, pp 337-378.

119. Domingos, R. F.; Baalousha, M. A.; Ju-Nam, Y.; Reid, M. M.; Tufenkji, N.; Lead, J. R.; Leppard, G. G.; Wilkinson, K. J., Characterizing manufactured nanoparticles in the environment: Multimethod determination of particle sizes. Environ. Sci. Technol. 2009, 43, (19), 7277-7284.

120. Chen, K. L.; Mylon, S. E.; Elimelech, M., Aggregation kinetics of alginate-coated hematite nanoparticles in monovalent and divalent electrolytes. Environ. Sci. Technol. 2006, 40, (5), 1516-1523.

121. Ruckenstein, E.; Prieve, D. C., Rate of deposition of Brownian particles under the action of London and doublelayer forces. Journal of the Chemical Society, Faraday Transactions 2: Molecular and Chemical Physics 1973, 69, 1522-1536.

122. Spielman, L. A.; Friedlander, S. K., Role of the electrical double layer in particle deposition by convective diffusion. J. Colloid Interface Sci. 1974, 46, (1), 22-31.

123. Logan, B. E., Environmental Transport Processes. John Wiley \& Sons, Inc.: New York, 1999.

124. Kretzschmar, R., Borkovec, M., Grolimund, D., Elimelech M., Mobile subsurface colloids and their role in contaminant transport. Advances in Agronomy 1999, 66, 121-194.

125. Sauerbrey, G., Verwendung von schwingquarzen zur wagung dunner schichten und zur mikrowagung. Z. Phys. 1959, 155, 206-222.

126. Rajagopalan, R.; Tien, C., Trajectory analysis of deep-bed filtration with the sphere-in-cell porous media model. AIChE Journal 1976, 22, (3), 523-533.

127. Levich, V. G., Physicochemical hydrodynamics. Prentice Hall: Englewood Cliffs, NJ, 1962.

128. Song, L.; Elimelech, M., Deposition of Brownian particles in porous media: Modified boundary conditions for the sphere-in-cell model. J. Colloid Interface Sci. 1992, 153, (1), 294-297.

129. De Kerchove, A. J.; Elimelech, M., Structural growth and viscoelastic properties of adsorbed alginate layers in monovalent and divalent salts. Macromolecules 2006, 39, (19), 6558-6564.

130. Han, Z., Zhang, F., Lin, D., Xing, B., Clay minerals affect the stability of surfactant-facilitated carbon nanotube suspensions. Environ. Sci. Technol. 2008, 42, 6869-6875.

131. Saleh, N. B.; Pfefferle, L. D.; Elimelech, M., Influence of Biomacromolecules and Humic Acid on Aggregation Kinetics of Single-Walled Carbon Nanotubes. Environ. Sci. Technol. 2010, 44, 2412-2418.

132. Alargova, R. G., Deguchi, S., Tsujii, K., Stable colloidal dispersions of fullerenes in polar organic solvents. J. American Chemical Soc. 2001, 123, 10460-10467.

133. Dresselhaus, M. S. D., G.; Eklund, P. C., Science of Fullerenes and Carbon Nanotubes. Academic Press: San Diego, CA, , 1996.

134. Labille, J., Brant, J., Villieras, F., Pelletier, M., Thill, A., Masion, A., Wiesner, M., Rose, J., Bottero, J-Y., Affinity of $\mathrm{C}_{60}$ fullerenes with water. Fullerenes, Nanotubes, and Carbon Nanostructures 2006, 14, 307-314.

135. Labille, J.; Masion, A.; Ziarelli, F.; Rose, J.; Brant, J.; Villieras, F.; Pelletier, M.; Borschneck, D.; Wiesner, M. R.; Bottero, J. Y., Hydration and dispersion of C-60 in aqueous systems: The nature of water-fullerene interactions. Langmuir 2009, 25, (19), 11232-11235.

136. Hyung, H.; Kim, J. H., Natural organic matter (NOM) adsorption to multi-walled carbon nanotubes: Effect of NOM characteristics and water quality parameters. Environ. Sci. Technol. 2008, 42, (12), 4416-4421.

137. Phenrat, T., Liu, Y. Q., Tilton, R. D., Lowry, G. V., Adsorbed polyelectrolyte coatings decrease Fe-0 nanoparticle reactivity with TCE in water: Conceptual model and mechanisms. Environ. Sci. Technol. 2009, 43, (5), 1507-1514.

138. Saleh, N.; Sirk, K.; Liu, Y.; Phenrat, T.; Dufour, B.; Matyjaszewski, K.; Tilton, R. D.; Lowry, G. V., Surface modifications enhance nanoiron transport and NAPL targeting in saturated porous media. Environmental Engineering Science 2007, 24, (1), 45-57. 
139. Burleson, D. J.; Driessen, M. D.; Penn, R. L., On the characterization of environmental nanoparticles. Journal of Environmental Science and Health - Part A Toxic/Hazardous Substances and Environmental Engineering 2004, 39, (10), 2707-2753.

140. Chen, K. L.; Smith, B. A.; Ball, W. P.; Fairbrother, D. H., Assessing the colloidal properties of engineered nanoparticles in water: case studies from fullerene $\mathrm{C}_{60}$ nanoparticles and carbon nanotubes. Environ. Chem. 2010, 7, 118.

141. Gottschalk, F.; Sonderer, T.; Scholz, R. W.; Nowack, B., Modeled environmental concentrations of engineered nanomaterials (TiO2, $\mathrm{ZnO}, \mathrm{Ag}$, CNT, fullerenes) for different regions. Environ. Sci. Technol. 2009, 43, (24), 9216-9222. 142. Tiede, K.; Boxall, A. B. A.; Tear, S. P.; Lewis, J.; David, H.; Hassellov, M., Detection and characterization of engineered nanoparticles in food and the environment. Food Additives and Contaminants - Part A Chemistry, Analysis, Control, Exposure and Risk Assessment 2008, 25, (7), 795-821.

143. Gregory, J., Approximate expressions for retarded van der waals interaction. J. Colloid Interface Sci. 1981, 83, (1), 138-145.

144. Byrd, T. L.; Walz, J. Y., Interaction force profiles between Cryptosporidium parvum oocysts and silica surfaces. Environ. Sci. Technol. 2005, 39, (24), 9574-9582.

145. de Gennes, P. G., Polymers at an interface; a simplified view. Advances in Colloid and Interface Science 1987, 27, (3-4), 189-209. 
Table 1. Key Equations to Evaluate Particle-Particle and Particle-Surface Interactions

\begin{tabular}{|c|c|c|c|}
\hline $\begin{array}{c}\text { Interactio } \\
\text { n } \\
\text { Geometr } \\
y\end{array}$ & $\begin{array}{c}\text { Type of } \\
\text { Interactio } \\
\mathbf{n}\end{array}$ & Expression $^{a}$ & Ref \\
\hline $0-1$ & EDL & $\begin{array}{l}V_{E D L}=64 \pi \varepsilon_{0} \varepsilon_{r} a_{p}\left(k_{B} T / z e\right)^{2} \Gamma_{1} \Gamma_{2} \exp (-\kappa h) \\
\text { (3) }\end{array}$ & $\begin{array}{c}103 \\
)\end{array}$ \\
\hline $0-1$ & VDW & $\begin{array}{l}V_{V D W}=\frac{A_{123} a_{p}}{6 h(1+14 h / \lambda)} \\
\text { (4) }\end{array}$ & $\begin{array}{c}143 \\
)\end{array}$ \\
\hline $0-1$ & STERIC $^{b}$ & $\begin{array}{l}F_{S T}(h)=2 \pi a_{p}\left(\frac{k_{B} T}{s^{3}}\right)\left\{\frac{8 l}{5}\left[\left(\frac{2 l}{h}\right)^{5 / 4}-1\right]+\frac{8 l}{7}\left[\left(\frac{h}{2 l}\right)^{7 / 4}-1\right]\right\} \\
\text { (5a) } \\
V_{S T}(h)=-\int_{\infty}^{h} F_{S T}(h) d h \\
\text { (5b) }\end{array}$ & $\begin{array}{l}(144 \\
145)\end{array}$ \\
\hline $0-0$ & EDL & $\begin{array}{l}V_{E D L}=64 \pi \frac{a_{1} a_{2}}{a_{1}+a_{2}}\left(\frac{k_{B} T}{z e}\right)^{2} \Gamma_{1} \Gamma_{2} \exp (-\kappa h) \\
\text { (6) }\end{array}$ & $\begin{array}{c}103 \\
)\end{array}$ \\
\hline $0-0$ & VDW & $\begin{array}{l}V_{V D W}=-\frac{A_{121} a_{1} a_{2}}{6 h\left(a_{1}+a_{2}\right)(1+14 h / \lambda)} \\
(7)\end{array}$ & $\begin{array}{c}(143 \\
)\end{array}$ \\
\hline $0-0$ & STERIC & $\begin{array}{l}F_{S T}(h)=2 \pi\left(\frac{a_{1} a_{2}}{a_{1}+a_{2}}\right)\left(\frac{k_{B} T}{s^{3}}\right)\left\{\frac{8 l}{5}\left[\left(\frac{2 l}{h}\right)^{5 / 4}-1\right]+\frac{8 l}{7}\left[\left(\frac{h}{2 l}\right)^{7 / 4}-1\right]\right\} \text { (8a) } \\
V_{S T}(h)=-\int_{\infty}^{h} F_{S T}(h) d h \\
\text { (8b) }\end{array}$ & $\begin{array}{l}(144 \\
145)\end{array}$ \\
\hline
\end{tabular}

${ }^{a}$ All variables are defined in the Nomenclature section.

bThis expression is for the case where both the particle and the surface are polymercoated. For the case where only a single surface is polymer-coated, a factor of 2 is removed preceding each / term in eq. 5 a. 
Table 2. Summary of Laboratory Studies on Nanoparticle Aggregation

\begin{tabular}{|c|c|c|c|c|c|}
\hline $\begin{array}{l}\text { nanoparticle } \\
\text { type }\end{array}$ & $\begin{array}{l}\text { nominal size and } \\
\text { concentration }\end{array}$ & experimental approach & solution chemistry & main findings and conclusions & references \\
\hline$n \mathrm{~B}$ & $\begin{aligned} d_{\text {TEM }} & =25 \mathrm{~nm} \\
C & =n / a\end{aligned}$ & DLS & $\begin{array}{l}20-1000 \mathrm{mM} \mathrm{NaCl} \\
0.2-20 \mathrm{mM} \mathrm{MgCl}_{2} \\
0.2-10 \mathrm{mM} \mathrm{CaCl}_{2} \\
\mathrm{pH} 5.6\end{array}$ & $\begin{array}{l}\text { Aggregation is similar to classical colloidal particles and } \\
\text { follows DLVO theory }\end{array}$ & Liu et al. 2009 \\
\hline $\begin{array}{l}n \mathrm{C}_{60,} n \mathrm{C}_{70} \text { and } \\
\text { organic } \\
\text { derivatives } \\
\end{array}$ & $\begin{array}{l}d=n / a \\
C=n / a\end{array}$ & DLS & $10 \mathrm{mM} \mathrm{NaCl}, \mathrm{pH} 4-10$ & $\begin{array}{l}\text { Isoelectric point } ~ 0 \text {, nanoparticles stable at } \mathrm{pH}>3.0 \text {; } \\
\text { synthesis parameters control their stability and fate }\end{array}$ & $\begin{array}{l}\text { Ma and Bouchard, } \\
2009\end{array}$ \\
\hline$n \mathrm{C}_{60}$ & $\begin{array}{c}\mathrm{d}_{\mathrm{DLS}}=101.0 \mathrm{~nm} \\
11.62 \mathrm{mg} / \mathrm{L} \\
\mathrm{d}_{\mathrm{DLS}}=166.2 \mathrm{~nm} \\
3.34 \mathrm{mg} / \mathrm{L}\end{array}$ & time-resolved DLS & $10-1000 \mathrm{mM} \mathrm{KCl}, \mathrm{pH}=5.5$ & $\begin{array}{l}\mathrm{nC}_{60} \text { prepared by prolonged stirring in water more stable } \\
\text { than } \mathrm{nC}_{60} \text { prepared by sonication in toluene; stability curves } \\
\text { in agreement with DLVO theory }\end{array}$ & $\begin{array}{l}\text { Chen and Elimelech, } \\
2009\end{array}$ \\
\hline $\begin{array}{c}n \mathrm{C}_{60} \text { and } \\
\text { organic } \\
\text { derivatives }\end{array}$ & $\begin{array}{c}d=n / a \\
0.22-2.42 \mathrm{mg} / \mathrm{L}\end{array}$ & time-resolved DLS & $25-1000 \mathrm{mM} \mathrm{NaCl}, \mathrm{pH}=\mathrm{n} / \mathrm{a}$ & $\begin{array}{l}\text { Presence of phenyl alkyl ester moieties increases colloidal } \\
\text { stability }\end{array}$ & $\begin{array}{l}\text { Bouchard et al. } \\
\quad 2009\end{array}$ \\
\hline$n \mathrm{C}_{60}$ & $\begin{array}{c}\mathrm{d}_{\mathrm{DLS}}=92 \pm 0.3 \mathrm{~nm} \\
1.0-2.7 \mathrm{mg} / \mathrm{L}\end{array}$ & DLS & $\begin{array}{c}1-100 \mathrm{mM} \mathrm{NaCl} \\
1-100 \mathrm{mM} \mathrm{CaCl}_{2} \\
\mathrm{pH} 7.0 \\
\end{array}$ & $\begin{array}{c}\text { Suspension stable at } \leq 1 \mathrm{mM} \text { ionic strength, regardless of } \\
\text { electrolyte species, solution addition rate, or mixing } \\
\text { sequence }\end{array}$ & Wang et al. 2008 \\
\hline$n \mathrm{C}_{60}$ & $\begin{array}{c}\mathrm{d}_{\mathrm{TEM}}=59.2 \pm 22.7 \mathrm{~nm} \\
5.92 \mathrm{mg} / \mathrm{L}\end{array}$ & $\begin{array}{l}\text { time-resolved DLS } \\
\text { TEM }\end{array}$ & $\begin{array}{c}90-650 \mathrm{mM} \mathrm{NaCl} \pm 1-5 \mathrm{mg} / \mathrm{L} \mathrm{HA} \\
4-100 \mathrm{mM} \mathrm{MgCl}_{2} \pm 1 \mathrm{mg} / \mathrm{L} \mathrm{HA} \\
2.5-40 \mathrm{mM} \mathrm{CaCl}_{2} \pm 1 \mathrm{mg} / \mathrm{L} \mathrm{HA} \\
\mathrm{pH} 7.5-8.5\end{array}$ & $\begin{array}{l}\text { Aggregation kinetics consistent with DLVO theory; } \mathrm{HA} \\
\text { increases } \mathrm{nC}_{60} \text { stability at low ionic strength due to steric } \\
\text { repulsion; at > } 10 \mathrm{mM} \mathrm{CaCl}_{2} \text {, intermolecular bridging of } \mathrm{HA} \\
\text { macromolecules with } \mathrm{Ca}^{2+} \text { results in increased light } \\
\text { scattering and } \mathrm{a}>1.0\end{array}$ & $\begin{array}{l}\text { Chen and Elimelech, } \\
2007\end{array}$ \\
\hline$n \mathrm{C}_{60}$ & $\begin{aligned} \mathrm{d}_{\mathrm{TEM}} & =59.2 \pm 22.7 \mathrm{~nm} \\
& 5.92 \mathrm{mg} / \mathrm{L}\end{aligned}$ & time-resolved DLS & $\begin{array}{l}60-350 \mathrm{mM} \mathrm{NaCl} \\
2.5-20 \mathrm{mM} \mathrm{CaCl}_{2} \\
\mathrm{pH} 5.2\end{array}$ & $\begin{array}{l}\text { Stability ratios in good agrement with DLVO theory with } \\
\text { reaction-limited and diffusion-limited aggregation zones } \\
\text { clearly defined; } \mathrm{CCCs} \text { at } 120 \text { and } 4.8 \mathrm{mM} \text { for } \mathrm{NaCl} \text { and } \\
\qquad \mathrm{CaCl}_{2} \text {, respectively }\end{array}$ & $\begin{array}{l}\text { Chen and Elimelech, } \\
2006\end{array}$ \\
\hline$n \mathrm{C}_{60}$ and $n \mathrm{C}_{70}$ & $\begin{aligned} d_{D L S} & =63 \mathrm{~nm} \\
C & =n / a\end{aligned}$ & $\begin{array}{l}\text { DLS } \\
\text { TEM }\end{array}$ & $171 \mathrm{mM} \mathrm{NaCl}, \mathrm{pH}=\mathrm{n} / \mathrm{a}$ & $\begin{array}{l}\text { Monodisperse and polycrystalline } \mathrm{nC}_{60} \text { clusters negatively } \\
\text { charged and stable in pure water due to electrostatic } \\
\text { repulsion; adding salt destabilizes cluster suspension }\end{array}$ & Deguchi et al. 2001 \\
\hline$n \mathrm{C}_{60}$ & $\begin{array}{c}\mathrm{d}_{\mathrm{TEM}}=7-36 \mathrm{~nm} \\
130 \mathrm{mg} / \mathrm{L}\end{array}$ & TEM & DI water, $\mathrm{pH}=\mathrm{n} / \mathrm{a}$ & $\begin{array}{c}\mathrm{nC}_{60} \text { nanoparticles form fractal clusters in hydrated state; } \\
\text { size of individual clusters can be as low as } 1-4 \mathrm{~nm}\end{array}$ & $\begin{array}{l}\text { Andrievsky et al. } \\
1999 \\
\end{array}$ \\
\hline$n \mathrm{C}_{60}$ & $\begin{array}{c}\mathrm{d} \leq 200 \mathrm{~nm} \\
80-140 \mathrm{mg} / \mathrm{L}\end{array}$ & UV-Vis spectroscopy & 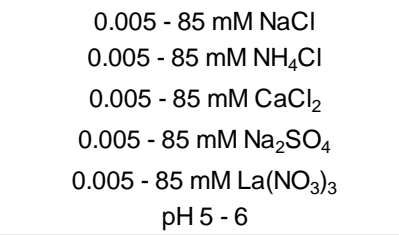 & $\begin{array}{c}\mathrm{nC}_{60} \text { nanoparticles behave as typical colloidal particles } \\
\text { and follow Schulze-Hardy rule }\end{array}$ & $\begin{array}{l}\text { Mchedlov- } \\
\text { Petrossyan et al. } \\
1997\end{array}$ \\
\hline
\end{tabular}




\begin{tabular}{|c|c|c|c|c|c|}
\hline $\begin{array}{l}\text { fullerols } \\
\left(\mathrm{C}_{60}(\mathrm{OH})_{n}\right)\end{array}$ & $\begin{array}{c}d_{\text {TEM }}=100-250 \mathrm{~nm} \\
30-220 \mathrm{mg} / \mathrm{L}\end{array}$ & $\begin{array}{l}\text { UV-vis spectroscopy } \\
\text { SEM } \\
\text { TEM }\end{array}$ & 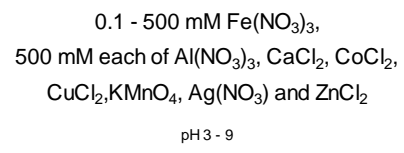 & $\begin{array}{l}\text { Fullerols react rapidly with metal to produce metal-fullerol } \\
\text { cross-linked aggregates }\end{array}$ & $\begin{array}{l}\text { Anderson and } \\
\text { Barron, } 2005\end{array}$ \\
\hline MWNTs & $\begin{array}{c}\mathrm{d}_{\mathrm{TEM}}=0.6 \pm 0.5 \mathrm{~nm} \\
\mathrm{~L}=0.1-5.8 \mathrm{~mm} \\
0.75-7.5 \mathrm{mg} / \mathrm{L}\end{array}$ & $\begin{array}{l}\text { Time-resolved DLS } \\
\text { TEM } \\
\text { AFM } \\
\text { XPS } \\
\end{array}$ & $35-900 \mathrm{mM} \mathrm{NaCl}, \mathrm{pH} 4,6$ and 8 & $\begin{array}{c}\text { Good correlation between CCC, total oxygen concentration, } \\
\text { and MWNT surface charge }\end{array}$ & Smith et al. 2009 \\
\hline MWNTs & $\begin{aligned} \mathrm{d}_{\mathrm{TEM}} & =0.6 \pm 0.5 \mathrm{~nm} \\
\mathrm{~L} & =0.1-5.8 \mathrm{~mm} \\
& <3.0 \mathrm{mg} / \mathrm{L}\end{aligned}$ & Time-resolved DLS & $\begin{array}{c}30-900 \mathrm{mM} \mathrm{NaCl} \\
30-200 \mathrm{mM} \mathrm{Na}_{2} \mathrm{SO}_{4} \\
1-8 \mathrm{mM} \mathrm{MgCl}_{2} \\
0.7-6.2 \mathrm{mM} \mathrm{CaCl}_{2}\end{array}$ & $\begin{array}{c}\text { Oxidized MWNT CCC values consistent with electrostatic } \\
\text { stabilization; surface charge correlates with pH-dependent } \\
\text { MWNT colloidal stability variations }\end{array}$ & Smith et al. 2009 \\
\hline MWNTs & $\begin{array}{c}\mathrm{d}_{\mathrm{TEM}}<10-100 \mathrm{~nm} \\
\mathrm{~L}=1-2 \mathrm{~mm} \\
100-200 \mathrm{mg} / \mathrm{L}\end{array}$ & $\begin{array}{l}\text { TEM } \\
\text { UV-vis spectroscopy }\end{array}$ & $\begin{array}{c}1-20 \mathrm{mM} \mathrm{Na}+25 \mathrm{mg} / \mathrm{L} \mathrm{TA} \\
0.05-1.0 \mathrm{mM} \mathrm{Mg}+25 \mathrm{mg} / \mathrm{L} \mathrm{TA} \\
0.05-1.0 \mathrm{mM} \mathrm{Ca}+25 \mathrm{mg} / \mathrm{L} \mathrm{TA} \\
0-0.04 \mathrm{mM} \mathrm{La}+25 \mathrm{mg} / \mathrm{L} \mathrm{TA} \\
\mathrm{pH} 3-11 \\
\end{array}$ & $\begin{array}{l}\text { Aggregation rate independent of MWNT diameter; CCC } \\
\text { values proportional to valence by an exponential factor of } \\
5.5\end{array}$ & Lin et al. 2009 \\
\hline MWNTs & $\begin{array}{c}\mathrm{d}^{\star}=140 \pm 30 \mathrm{~nm} \\
\mathrm{~L}=7 \pm 2 \mathrm{~mm} \\
50-500 \mathrm{mg} / \mathrm{L}\end{array}$ & $\begin{array}{l}\text { Thermal optical transmittance } \\
\text { analyzer } \\
\text { UV-vis spectroscopy }\end{array}$ & $\begin{array}{c}\text { river water } \\
1 \% \mathrm{SDS} \pm 10-100 \mathrm{mg} / \mathrm{L} \mathrm{NOM} \\
\mathrm{pH}=\mathrm{n} / \mathrm{a}\end{array}$ & $\begin{array}{l}\text { MWNTs remain stable in presence of organic matter and } \\
\text { river water; stability increases in presence of surfactant }\end{array}$ & Hyung et al. 2007 \\
\hline MWNTs & $\begin{array}{c}\mathrm{d}_{\mathrm{TEM}}=17.6 \pm 7.9 \mathrm{~nm} \\
\mathrm{~L}=1.5 \pm 1.5 \mathrm{~mm} \\
\mathrm{C}=\mathrm{n} / \mathrm{a}\end{array}$ & Time-resolved DLS & $\begin{array}{c}1-500 \mathrm{mM} \mathrm{NaCl} \pm 5 \mathrm{mg} / \mathrm{L} \mathrm{HA} \\
0.1-30 \mathrm{mM} \mathrm{CaCl}_{2} \pm 5 \mathrm{mg} / \mathrm{L} \mathrm{HA} \\
0.05-30 \mathrm{mM} \mathrm{MgCl}_{2} \pm 5 \mathrm{mg} / \mathrm{L} \mathrm{HA} \\
\mathrm{pH} 3-9\end{array}$ & $\begin{array}{l}\text { Electrostatic interactions control MWNT stability in } \\
\text { electrolyte solutions; humic acid increases MWNT stability } \\
\text { due to steric repulsion }\end{array}$ & Saleh et al. 2008 \\
\hline MWNTs & $\begin{aligned} & d=10-30 \mathrm{~nm} \\
& L=10-30 \mathrm{~mm} \\
& C=\mathrm{n} / \mathrm{a}\end{aligned}$ & DLS & $100 \mathrm{mg} / \mathrm{L} \mathrm{NOM}, \mathrm{pH}=\mathrm{n} / \mathrm{a}$ & $\begin{array}{l}\text { Functionalization increases stability: (hydroxyl-modified > } \\
\qquad \text { carboxyl-modified > bare) }\end{array}$ & Kennedy et al. 2008 \\
\hline MWNTs & $\begin{array}{l}\mathrm{d}_{\mathrm{TEM}} \sim 30 \mathrm{~nm} \\
\quad 50 \mathrm{mg} / \mathrm{L}\end{array}$ & UV-vis spectroscopy & $\begin{array}{c}\text { DI water } \\
172 \mathrm{mM} \mathrm{NaCl} \\
\mathrm{pH} 0-12 \\
\end{array}$ & $\begin{array}{l}\mathrm{COOH} \text { functionalized MWNTs stable at } \mathrm{pH} \geq 4 \text { as a result of } \\
\text { carboxylic acid deprotonation to carboxylate anions }\end{array}$ & Shieh et al. 2007 \\
\hline SWNTs & $\begin{array}{c}d=n / a \\
100 \mathrm{mg} / \mathrm{L}\end{array}$ & $\begin{array}{c}\text { absorbance } \\
\text { spectroscopy/photoluminesce } \\
\text { nce }\end{array}$ & $\begin{array}{c}57.5-570 \mathrm{mM} \mathrm{NaCl}+1 \% \mathrm{SDS} \\
8.75 \mathrm{mM} \mathrm{MgSO}_{4}+1 \% \mathrm{SDS} \\
6.9 \mathrm{mM} \mathrm{MgCl}_{2}+1 \% \mathrm{SDS} \\
3.8 \mathrm{mM} \mathrm{ErCl}_{3}+1 \% \mathrm{SDS} \\
\mathrm{pH}=\mathrm{n} / \mathrm{a}\end{array}$ & $\begin{array}{l}\text { Once intertube van der Waals attraction overcome by } \\
\text { sonication, SDS sorbed to SWNTs prevents reaggregation }\end{array}$ & Niyogi et al. 2007 \\
\hline SWNTs & $\begin{array}{l}\mathrm{d}^{*}=1.2 \mathrm{~nm} \\
<600 \mathrm{mg} / \mathrm{L}\end{array}$ & UV-vis spectroscopy & $\begin{array}{c}1-100 \mathrm{mM} \mathrm{NaCl} \\
(-) \mathrm{mM} \mathrm{KCl}, \mathrm{MgCl}_{2}, \mathrm{CaCl}_{2}, \mathrm{LaCl}_{3} \text {, and } \\
\mathrm{CeCl}_{3} \\
\mathrm{pH}=\mathrm{n} / \mathrm{a}\end{array}$ & $\begin{array}{l}\text { SWNTs treated with } \mathrm{H}_{2} \mathrm{SO}_{4} / \mathrm{H}_{2} \mathrm{O}_{2} \text { well-dispersed in water; } \\
\text { CCC values follow Schulze-Hardy rule }\end{array}$ & Sano et al. 2001 \\
\hline SWNTs & $\mathrm{d}^{*}=0.9-1.4 \mathrm{~nm}$ & Time-resolved DLS & $\begin{array}{cc} & 1-100 \mathrm{mM} \mathrm{NaCl} \\
\mathrm{pH} 6 & 0.1-10 \mathrm{mM} \mathrm{CaCl}_{2} \\
2.5 \mathrm{mg} / \mathrm{L} \text { (as TOC) of HA and } \\
\text { biomacromolecules }\end{array}+$ & $\begin{array}{l}\text { HA and biomacromolecules (BSA, alginate, LB) impart } \\
\text { steric stabilization; BSA had the most dramatic effect due } \\
\text { to its globular molecular structure. }\end{array}$ & Saleh et al. 2010 \\
\hline QD & $\begin{array}{c}\mathrm{d}^{\star}=3.5-4.5 \mathrm{~nm} \\
680 \mathrm{mg} / \mathrm{L}\end{array}$ & DLS & $\begin{array}{c}0-150 \mathrm{mM} \mathrm{KCl} \\
0-20 \mathrm{mM} \mathrm{CaCl}_{2} \\
0-20 \mathrm{mM} \mathrm{MgCl}_{2} \\
0-13.3 \mathrm{mM} \mathrm{Al}_{2}\left(\mathrm{SO}_{4}\right)_{3} \\
\mathrm{pH} 5,8\end{array}$ & $\begin{array}{l}\text { QD stability controlled by ionic nature in solution; divalent } \\
\text { and trivalent cations form strong complexes with QD } \\
\text { capping ligands/functional groups, bridging QDs or } \\
\text { neutralizing their surface charges }\end{array}$ & Zhang et al. 2008 \\
\hline
\end{tabular}




\begin{tabular}{|c|c|c|c|c|c|}
\hline QD & $\begin{array}{l}\mathrm{d}^{*}=3.5 \mathrm{~nm} \\
100 \mathrm{mg} / \mathrm{L}\end{array}$ & $\begin{array}{l}\text { DLS } \\
\text { Microscopy }\end{array}$ & DI water, $\mathrm{pH} 3-12$ & $\begin{array}{l}\text { Decrease in pH causes surface ligands/functional group } \\
\text { detachment; surface protonation promotes QD aggregation }\end{array}$ & Zhang et al. 2008 \\
\hline QD & $\begin{array}{c}d=n / a \\
0.37-0.67 \mathrm{mM}(\mathrm{Cd})\end{array}$ & FCS & $\begin{array}{c}1-100 \mathrm{mM} \mathrm{Na}_{2} \mathrm{HPO}_{4}+0.2-20 \mathrm{mM} \\
\mathrm{KH}_{2} \mathrm{PO}_{4}+0.3-27 \mathrm{mM} \mathrm{KCl}+1.4-1370 \\
\mathrm{mM} \mathrm{NaCl} \\
\mathrm{pH}=7.4-9.0\end{array}$ & $\begin{array}{l}\text { Aggregation rate depends on QD size (small QDs } \\
\text { aggregate quickly); above 'photoactivation critical } \\
\text { concentration', aggregation and subsequent } \\
\text { photoactivation rapid under laser irradiation }\end{array}$ & Dong et al. 2007 \\
\hline$n \mathrm{Ag}$ & $\begin{array}{c}\mathrm{d}_{\mathrm{TEM}}=1-3 \mathrm{~nm} \\
\mathrm{C}=\mathrm{n} / \mathrm{a}\end{array}$ & $\begin{array}{l}\text { UV-vis spectroscopy } \\
\text { TEM }\end{array}$ & $\begin{array}{c}0-800 \mathrm{mM} \mathrm{Ba}^{2+} \\
0-800 \mathrm{mM} \mathrm{Ca}^{2+} \\
0-20 \mathrm{mM} \text { each of } \mathrm{Zn}^{2+}, \mathrm{Cr}^{3+}, \mathrm{Cu}^{2+}, \mathrm{Pb}^{2+} \\
\mathrm{pH}=9.3\end{array}$ & $\begin{array}{l}\text { Change in position of absorption spectra during cation } \\
\text { induced aggregation useful in identifying interaction } \\
\text { mechanism between Ag nanoparticles and electrophilic } \\
\text { transition metal cations or less polarizable alkaline metals }\end{array}$ & Liu et al. 2003 \\
\hline$n \mathrm{Ag}$ & $\begin{array}{c}d_{D L S}=23-42 \mathrm{~nm} \\
0.26-7.0 \times 10^{9} \text { particles } / \mathrm{L}\end{array}$ & $\begin{array}{c}\text { DLS } \\
\text { UV-vis spectroscopy }\end{array}$ & $\begin{array}{c}10-1000 \mathrm{mM} \mathrm{NaCl} \\
200 \mathrm{mM} \mathrm{NaCl}+0.005-0.1 \% \text { hydroxy- } \\
\text { ethylcellulose } \\
\mathrm{pH}=\mathrm{n} / \mathrm{a}\end{array}$ & $\begin{array}{c}\text { Fractal dimensions increase with time in reaction limited } \\
\text { aggregation regime but not in diffusion limited aggregation } \\
\text { regime }\end{array}$ & Trinh et al. 2009 \\
\hline$n \mathrm{ZVI}$ & $\begin{array}{l}\mathrm{d}=\mathrm{n} / \mathrm{a} \\
1 \mathrm{mg} / \mathrm{L}\end{array}$ & $\begin{array}{l}\text { photography } \\
\text { spectroscopy }\end{array}$ & $\begin{array}{c}1.2 \mathrm{mM} \mathrm{NaHCO}_{3} \pm 20-200 \mathrm{mg} / \mathrm{L} \mathrm{NOM}, \\
\mathrm{pH} 7.1\end{array}$ & $\begin{array}{c}\text { NOM sorption onto nZVI results in reduced sticking } \\
\text { coefficient and enhanced stability }\end{array}$ & Johnson et al. 2009 \\
\hline$n Z \mathrm{VI}$ & $\begin{array}{c}d_{D L S}=\leq 200 \mathrm{~nm} \\
154 \mathrm{mg} / \mathrm{L}\end{array}$ & DLS & $\begin{array}{c}\leq 500 \mathrm{mM} \mathrm{NaCl} \leq 1 \mathrm{~g} / \mathrm{L} \text { guar gum } \\
\leq 10 \mathrm{mM} \mathrm{CaCl}_{2} \pm \leq 1 \mathrm{~g} / \mathrm{L} \text { guar gum } \\
\mathrm{pH} 7.0\end{array}$ & $\begin{array}{l}\text { At high salt concentrations }(500 \mathrm{mM} \mathrm{NaCl} \text { and } 3 \mathrm{mM} \\
\left.\qquad \mathrm{CaCl}_{2}\right) \text {, guar gum stabilizes } \mathrm{ZVI}\end{array}$ & Tiraferri et al. 2008 \\
\hline$n Z \mathrm{VI}$ & $\begin{array}{c}\mathrm{d}_{\mathrm{TEM}}=10-80 \mathrm{~nm} \\
3000 \mathrm{mg} / \mathrm{L}\end{array}$ & DLS & $\begin{array}{c}1 \mathrm{mM} \mathrm{NaHCO}_{3} \pm 5-1000 \mathrm{mg} / \mathrm{L} \\
\text { polystyrene sulfonate } \\
1 \mathrm{mM} \mathrm{NaHCO}_{3} \pm 5-1000 \mathrm{mg} / \mathrm{L} \mathrm{CMC} \\
1 \mathrm{mM} \mathrm{NaHCO}_{3} \pm 5-1000 \mathrm{mg} / \mathrm{L} \mathrm{PA} \\
\mathrm{pH} 9.5-10.5\end{array}$ & $\begin{array}{l}\text { Larger ZVI particles unstable due to strong attractive } \\
\text { magnetic forces }\end{array}$ & Phenrat et al. 2008 \\
\hline$n Z \mathrm{VI}$ & $\begin{array}{c}d_{D L S}=15.2-3000 \mathrm{~nm} \\
C=n / a\end{array}$ & DLS & $\begin{array}{c}\leq 200 \mathrm{mM} \mathrm{NaCl} \\
\leq 10 \mathrm{mM} \mathrm{CaCl} \\
\mathrm{pH}=\mathrm{n} / \mathrm{a}\end{array}$ & $\begin{array}{l}\text { High cation concentrations promote aggregation of stable } \\
\text { ZVI particles }\end{array}$ & He and Zhao, 2007 \\
\hline$n Z \mathrm{VI}$ & $\begin{array}{c}\mathrm{d}_{\text {TEM }}=10-80 \mathrm{~nm} \\
3000 \mathrm{mg} / \mathrm{L}\end{array}$ & $\begin{array}{c}\text { DLS } \\
\text { optical microscopy }\end{array}$ & $1 \mathrm{mM} \mathrm{NaHCO}, \mathrm{pH} 7.4$ & $\begin{array}{c}\text { Aggregation rapid; increased aggregation with increasing } \\
\text { saturation magnetization (magnetic moment) }\end{array}$ & Phenrat et al. 2007 \\
\hline$n \mathrm{TiO}_{2}$ & $\begin{array}{c}d_{R G}=6-7 \mathrm{~nm} \\
3000-10000 \mathrm{mg} / \mathrm{L}\end{array}$ & absorption spectroscopy & $500-2000 \mathrm{mM} \mathrm{KCl}, \mathrm{pH} 0-2.0$ & $\begin{array}{c}\text { Aggregation slow at } \mathrm{pH} 0.1-2.0 \text {; aggregate structure } \\
\text { depends on ionic strength and medium } \mathrm{pH}\end{array}$ & $\begin{array}{l}\text { Pavlova-Verevkina } \\
\text { et al. } 2009\end{array}$ \\
\hline$n \mathrm{TiO}_{2}$ & $\begin{array}{l}\mathrm{d}^{*}=5 \mathrm{~nm} \\
1 \mathrm{mg} / \mathrm{L}\end{array}$ & FCS & $\begin{array}{c}5-100 \mathrm{mM} \mathrm{NaNO}_{3} \pm 0.2-5 \mathrm{mg} / \mathrm{L} \mathrm{FA} \\
\mathrm{pH} 2-8\end{array}$ & $\begin{array}{c}\text { Rapid aggregation in vicinity of } \mathrm{pH}_{\mathrm{ZPC}} \text {; adsorbed } \mathrm{FA} \\
\text { increases nanoparticle stability due to increased steric } \\
\text { repulsion }\end{array}$ & $\begin{array}{l}\text { Domingos et al. } \\
\quad 2009\end{array}$ \\
\hline$n \mathrm{TiO}_{2}$ & $\begin{array}{l}d^{\star}=4-6 \mathrm{~nm} \\
80-83 \mathrm{mg} / \mathrm{L}\end{array}$ & DLS & $\begin{array}{c}4.5-16.5 \mathrm{mM} \mathrm{NaCl} \\
12.8 \mathrm{mM} \mathrm{CaCl} \\
\mathrm{pH} 4.8-8.2\end{array}$ & Aggregation rate significantly higher in $\mathrm{CaCl}_{2}$ than in $\mathrm{NaCl}$ & French et al. 2009 \\
\hline$n \mathrm{TiO}_{2}$ & $\begin{array}{c}\mathrm{d}^{*}=35 \mathrm{~nm} \\
2000 \mathrm{mg} / \mathrm{L}(40 \mathrm{mg} / \mathrm{g} \text { of soil) }\end{array}$ & DLS & $\begin{array}{c}50 \mathrm{~g} / \mathrm{L} \text { diluted soil solution } \\
\mathrm{pH} 6.15-8.58\end{array}$ & $\begin{array}{c}\text { In soil solution, high ionic strength and low DOC result in } \\
\text { heightened aggregation rates }\end{array}$ & Fang et al. 2008 \\
\hline$n \mathrm{TiO}_{2}$ & $\begin{array}{l}\mathrm{d}^{*}=5,32 \mathrm{~nm} \\
2-200 \mathrm{mg} / \mathrm{L}\end{array}$ & DLS & $\begin{array}{c}20 \mathrm{mM} \mathrm{NaCl} \pm 0.1-2.2 \mathrm{mM} \text { organic } \\
\text { acids, } \mathrm{pH} 2-6.5\end{array}$ & $\begin{array}{c}\text { Aggregation occurs at all pH values; finer particles } \\
\text { aggregate faster than larger particles }\end{array}$ & $\begin{array}{l}\text { Pettibone et al. } \\
2008\end{array}$ \\
\hline$n \mathrm{TiO}_{2}$ & $\begin{array}{r}d=n / a \\
30 \mathrm{mg} / \mathrm{L}\end{array}$ & DLS & $\begin{array}{c}0.01-10 \mathrm{mM} \mathrm{KCl} \\
1 \mathrm{mM} \text { each LiCl, KBr, CsCl, LiF } \\
\mathrm{pH} 2-12\end{array}$ & $\begin{array}{l}\text { Hydrated ion radius determines extent of adsorption; } \\
\text { isoelectric point changes due to ion adsorption }\end{array}$ & $\begin{array}{l}\text { Tkachenko et al. } \\
2006\end{array}$ \\
\hline$n \mathrm{TiO}_{2}$ & $\begin{array}{c}\mathrm{d}^{*}=7-20 \mathrm{~nm} \\
\mathrm{C}=\mathrm{n} / \mathrm{a}\end{array}$ & $\begin{array}{l}\text { fractal dimension } \\
\text { measurement }\end{array}$ & $\begin{array}{l}\text { DI water } \\
\mathrm{pH}=\mathrm{n} / \mathrm{a}\end{array}$ & $\begin{array}{l}\text { Diffusion-limited aggregation results in fractal-like } \\
\text { aggregates }\end{array}$ & Tseng and Lin, 2003 \\
\hline
\end{tabular}


Table 3. Summary of Laboratory Studies on Nanoparticle Deposition

\begin{tabular}{|c|c|c|c|c|c|c|}
\hline nanoparticle type & deposition system & particle size and concentration & collector surfaces & solution chemistry & main findings and conclusions & references \\
\hline$n \mathrm{Al}$ & $\begin{array}{c}\text { packed column } \\
\mathrm{H}: 16 \mathrm{~cm}, \mathrm{D}: 1.5 \mathrm{~cm}\end{array}$ & $\begin{array}{c}\mathrm{d}^{*}=100 \mathrm{~nm} \\
\text { large } 1-10 \mu \mathrm{m} \text { agglomerates } \\
50 \mathrm{mg} / \mathrm{L}\end{array}$ & $\begin{array}{l}\text { quartz sand } \\
d_{50}=n / a\end{array}$ & $0.01 \mathrm{M} \mathrm{NaCl}, \mathrm{pH} 4,7$ & $\begin{array}{l}\text { Greater mobility at } \mathrm{pH} 4 \\
\text { Aluminum oxide coated particles more } \\
\text { prone to leaching; leach most at } \mathrm{pH} 7\end{array}$ & Doshi et al. 2008 \\
\hline alumoxane & $\begin{array}{c}\text { packed column } \\
H: 9.25 \mathrm{~cm}, \mathrm{D}: 2.5 \mathrm{~cm}\end{array}$ & $\begin{array}{l}d_{D L S}=74 \mathrm{~nm} \\
0-10 \mathrm{mg} / \mathrm{L}\end{array}$ & $\begin{array}{c}\text { glass beads } \\
d=300-425 \mu \mathrm{m}\left(d_{50}=355 \mu \mathrm{m}\right)\end{array}$ & $0.01 \mathrm{M} \mathrm{NaCl}, \mathrm{pH} 7$ & High mobility; approximately $80 \%$ passage & Lecoanet et al. 2004 \\
\hline$n \mathrm{~B}$ & $\begin{array}{l}\text { packed column } \\
H: 15 \mathrm{~cm}, \mathrm{D}: 1.5 \mathrm{~cm}\end{array}$ & $\begin{array}{c}d_{\text {TEM }}=25 \mathrm{~nm} \quad \mathrm{~d}^{*}=10-20 \mathrm{~nm} \\
\mathrm{mg} / \mathrm{L}\end{array}$ & $\begin{array}{c}\text { quartz sand } \\
50 \mathrm{~d}=212-270 \mu \mathrm{m}\left(d_{50}=250 \mu \mathrm{m}\right)\end{array}$ & $\begin{array}{l}0.01-0.4 \mathrm{M} \mathrm{NaCl} \\
\mathrm{pH} 5.6\end{array}$ & $\begin{array}{l}\text { Attachment efficiency increases with } \\
\text { increasing IS up until } 0.2 \mathrm{M}\end{array}$ & Liu et al. 2009 \\
\hline$n \mathrm{CeO}_{2}$ & $\begin{array}{c}\text { model wastewater } \\
\text { treatment plant } \\
\text { (biological treatment only) }\end{array}$ & $\begin{array}{c}d_{X D C, T E M}=20-50 \mathrm{~nm} \\
100 \mathrm{mg} / \mathrm{L} \pm \text { dispersing agents }\end{array}$ & $\begin{array}{l}\text { fresh, stabilized clearing sludge } \\
1.5-2.5 \mathrm{~g} / \mathrm{L} \text { dry content }\end{array}$ & $\begin{array}{c}\mathrm{nCeO}_{2} \text {, synthetic wastewater and } \\
\text { drinking water mixed into aeration } \\
\text { chamber, } \mathrm{pH} 8-8.5\end{array}$ & $\begin{array}{l}\text { Significant portion of } n \mathrm{CeO}_{2} \text { present as } \\
\text { large aggregates, bound to bacteria; high } \\
\text { unagglomerated } n \mathrm{CeO}_{2} \text { levels }\end{array}$ & Limbach et al. 2008 \\
\hline$n \mathrm{CuO}$ & $\begin{array}{l}\text { 2-D flow cell } \\
\text { Length: } 11.3 \mathrm{~cm}\end{array}$ & $\begin{array}{c}\mathrm{d}^{*}=118-637 \mathrm{~nm} \\
\mathrm{~d}_{\mathrm{DLS}}=372 \mathrm{~nm} \\
9 \mathrm{mg} / \mathrm{L} \pm \mathrm{SDS} \\
\end{array}$ & $\begin{array}{l}\text { etched glass } \\
\mathrm{d}=0.87 \mathrm{~mm}\end{array}$ & $0.01 \mathrm{M} \mathrm{NaCl}, \mathrm{pH} 7$ & $\begin{array}{l}n \mathrm{CuO} \text { aggregates form within porous } \\
\text { medium; velocity affects aggregate } \\
\text { deposition density and location; SDS } \\
\text { enhances particle elution }\end{array}$ & Jeong \& Kim, 2009 \\
\hline ferroxane & $\begin{array}{c}\text { packed column } \\
H: 9.25 \mathrm{~cm}, \mathrm{D}: 2.5 \mathrm{~cm}\end{array}$ & $\begin{array}{l}d_{D L S}=303 \mathrm{~nm} \\
0-10 \mathrm{mg} / \mathrm{L}\end{array}$ & $\begin{array}{c}\text { glass beads } \\
d=300-425 \mu \mathrm{m}\left(d_{50}=355 \mu \mathrm{m}\right)\end{array}$ & $0.01 \mathrm{M} \mathrm{NaCl}, \mathrm{pH} 7$ & $\begin{array}{l}\text { Least mobile of } 8 \text { nanoparticles tested in } \\
\text { study; mobility appears to decrease with } \\
\text { time }\end{array}$ & Lecoanet et al. 2004 \\
\hline$n \mathrm{C}_{60}$ & $\begin{array}{c}\text { packed column } \\
H: 9.25 \mathrm{~cm}, \mathrm{D}: 2.5 \mathrm{~cm}\end{array}$ & $\begin{array}{c}\mathrm{d}_{\mathrm{DLS}, \mathrm{TEM}}=20,135,168 \mathrm{~nm} \\
0-10 \mathrm{mg} / \mathrm{L}\end{array}$ & $\begin{array}{l}\text { glass beads } \\
d_{50}=355 \mu \mathrm{m}\end{array}$ & $0.001,0.1 \mathrm{M} \mathrm{NaCl}, \mathrm{pH} 7$ & $\begin{array}{l}\text { Increased deposition with increasing IS; } \\
\text { repulsive interactions between EDLs key to } \\
n \mathrm{C}_{60} \text { stability in suspension }\end{array}$ & Brant et al. 2005 \\
\hline$n \mathrm{C}_{60}$ & QCM & $\begin{aligned} & \mathrm{d}_{\mathrm{DLS}}=50.5 \mathrm{~nm} \\
& 5.8 \mathrm{mg} / \mathrm{L}\end{aligned}$ & $\begin{array}{c}\text { silica surface } \\
\text { (bare or coated) }\end{array}$ & $\begin{array}{l}10-100 \mathrm{mM} \mathrm{NaCl}, \mathrm{pH} 5.5 \\
0.3-3 \mathrm{mM} \mathrm{CaCl}_{2}, \mathrm{pH} 5.5 \\
\end{array}$ & $\begin{array}{l}\text { Behavior consistent with DLVO theory; } \\
\text { humic acid and alginate decrease } \\
\text { deposition rate due to steric repulsion }\end{array}$ & $\begin{array}{l}\text { Chen and Elimelech, } \\
2008 \\
\end{array}$ \\
\hline$n \mathrm{C}_{60}$ & QCM-D & $\begin{array}{c}\mathrm{d}_{\mathrm{DLS}}=55.7 \mathrm{~nm} \\
\sim 3 \mathrm{mg} / \mathrm{L}\end{array}$ & silica surface & $\begin{array}{c}1-300 \mathrm{mM} \mathrm{NaCl}, \mathrm{pH} 5.2 \\
0.1-1.0 \mathrm{mM} \mathrm{CaCl}_{2}, \mathrm{pH} 5.2 \\
\end{array}$ & $\begin{array}{l}\text { Above } \mathrm{CCC} \text {, rate of deposition decreases } \\
\text { as a result of concurrent } n \mathrm{C}_{60} \text { aggregation }\end{array}$ & $\begin{array}{c}\text { Chen and Elimelech, } \\
2006 \\
\end{array}$ \\
\hline$n \mathrm{C}_{60}$ & $\begin{array}{l}\text { packed column } \\
\mathrm{H}: 5 \mathrm{~cm}, \mathrm{D}: 0.9 \mathrm{~cm}\end{array}$ & $\begin{array}{l}\mathrm{d}_{\text {TEM }} \sim 100 \mathrm{~nm} \\
48 \mathrm{mg} / \mathrm{L}\end{array}$ & $\begin{array}{c}\text { Iula soil } \\
\text { (92\% sand, } 6 \% \text { silt, } 2 \% \text { clay }) \\
d_{50} \sim 250 \mu \mathrm{m} \\
\end{array}$ & $\begin{array}{c}0.02 \mathrm{M}\left(\mathrm{NaCl}+\mathrm{NaN}_{3}\right) \\
\mathrm{pH} 6.7-7.2\end{array}$ & $\begin{array}{l}n \mathrm{C}_{60} \text { particles most mobile at higher } \\
\text { velocities; column ripening possibly } \\
\text { observed at low velocity }\end{array}$ & Cheng et al. 2005 \\
\hline$n \mathrm{C}_{60}$ & $\begin{array}{l}\text { packed column } \\
\mathrm{H}: 10 \mathrm{~cm}, \mathrm{D}: 2.65 \mathrm{~cm}\end{array}$ & $\begin{array}{c}T T A / n C_{60}: d_{D L S}=92 \mathrm{~nm} \\
1.26 \mathrm{mg} / \mathrm{L} \\
\mathrm{THF}_{\mathrm{hC}}{ }_{60}: \mathrm{d}_{\mathrm{DLS}}=111 \mathrm{~nm} \\
2.34 \mathrm{mg} / \mathrm{L} \\
\end{array}$ & $\begin{array}{l}\text { glass beads } \\
d_{50}=360 \mu \mathrm{m}\end{array}$ & $\begin{array}{c}0.01-0.6 \mathrm{M} \mathrm{NaCl} \pm \mathrm{TA} \text {, alginate, } \\
\mathrm{pH} 6.5-7.5 \\
\text { other electrolytes considered }\end{array}$ & $\begin{array}{l}\text { Increased deposition with increasing IS and } \\
\text { decreasing velocity; } \\
\text { transport affected by preparation method }\end{array}$ & Espinasse et al. 2007 \\
\hline$n \mathrm{C}_{60}$ & $\begin{array}{c}\text { packed column } \\
H: 4.3 \mathrm{~cm}, \mathrm{D}: 1.6 \mathrm{~cm}\end{array}$ & $\begin{array}{c}d_{D L S}=101 \mathrm{~nm} \\
65 \pm 5 \mu \mathrm{g} \text { (pulse injection) }\end{array}$ & $\begin{array}{c}\text { natural soil } \\
\text { (58\% sand, } 29 \% \text { clay, } 13 \% \text { silt) } \\
d=420-1000 \mu \mathrm{m}\end{array}$ & $\begin{array}{c}\mathrm{KCl} \text { or } \mathrm{CaCl}_{2} \text { (selected IS to } \\
\text { compare with SWNT studies), } \\
\mathrm{pH} 5.6-5.8\end{array}$ & $\begin{array}{l}\text { Compared to SWNT transport in soil packed } \\
\text { columns, fullerene deposition more sensitive } \\
\text { to IS; exhibits lower deposition rates }\end{array}$ & Jaisi \& Elimelech, 2009 \\
\hline$n \mathrm{C}_{60}$ & $\begin{array}{c}\text { packed column } \\
H: 9.25 \mathrm{~cm}, D: 2.5 \mathrm{~cm}\end{array}$ & $\begin{array}{c}d_{D L S}=168 \mathrm{~nm} \\
0-10 \mathrm{mg} / \mathrm{L} \text { (step function) }\end{array}$ & $\begin{array}{c}\text { glass beads } \\
\mathrm{d}=300-425 \mu \mathrm{m}\left(\mathrm{d}_{50}=355 \mu \mathrm{m}\right)\end{array}$ & $0.01 \mathrm{M} \mathrm{NaCl}, \mathrm{pH} 7$ & $\begin{array}{l}\text { Fullerenes experience greater retention than } \\
\text { fullerols and SWNTs }\end{array}$ & Lecoanet et al. 2004 \\
\hline$n \mathrm{C}_{60}$ & $\begin{array}{c}\text { packed column } \\
H: 9.25 \mathrm{~cm}, D: 2.5 \mathrm{~cm}\end{array}$ & $\begin{array}{l}d_{\text {DLS }}=168 \mathrm{~nm} \\
10 \mathrm{mg} / \mathrm{L}\end{array}$ & $\begin{array}{c}\text { glass beads } \\
\mathrm{d}=300-425 \mu \mathrm{m}\left(\mathrm{d}_{50}=355 \mu \mathrm{m}\right)\end{array}$ & $0.01 \mathrm{M} \mathrm{NaCl}, \mathrm{pH} 7$ & $\begin{array}{l}\text { Higher velocities alter break-through curve } \\
\text { appearance but do not result in increased } \\
\text { elution } \\
\end{array}$ & $\begin{array}{l}\text { Lecoanet \& Wiesner, } \\
2004 \\
\end{array}$ \\
\hline$n \mathrm{C}_{60}$ & $\begin{array}{l}\text { packed column } \\
H: 15 \mathrm{~cm}, \mathrm{D}: 2.5 \mathrm{~cm}\end{array}$ & $\begin{array}{l}d_{D L S}=120 \mathrm{~nm} \\
\quad 3 \mathrm{mg} / \mathrm{L}\end{array}$ & $\begin{array}{l}\text { Ottawa sand ( } 4 \text { fraction sizes) } \\
d_{50}=125,165,355,710 \mu \mathrm{m}\end{array}$ & $\begin{array}{c}3.065 \mathrm{mM}\left(\mathrm{CaCl}_{2}+\mathrm{NaHCO}_{3}\right) \\
\mathrm{pH} 7\end{array}$ & $\begin{array}{l}\text { Transport behavior not in agreement with } \\
\text { DLVO; primary minimum deposition } \\
\text { attributed to surface charge heterogeneities }\end{array}$ & Li et al. 2008 \\
\hline
\end{tabular}




\begin{tabular}{|c|c|c|c|c|c|c|}
\hline$n \mathrm{C}_{60}$ & $\begin{array}{c}\text { packed column } \\
H: 15 \mathrm{~cm}, \mathrm{D}: 2.5 \mathrm{~cm}\end{array}$ & $\begin{array}{l}d_{D L S}=95 \mathrm{~nm} \\
1-3 \mathrm{mg} / \mathrm{L}\end{array}$ & $\begin{array}{l}\text { Ottawa sand } \\
d_{50}=360 \mu \mathrm{m} \\
\text { glass beads } \\
d_{50}=360 \mu \mathrm{m}\end{array}$ & $1 \mathrm{mM} \mathrm{CaCl}_{2}, \mathrm{pH} 7$ & $\begin{array}{c}\text { Transport and deposition behavior } \\
\text { consistent with batch retention data and } \\
\text { DLVO theory }\end{array}$ & Wang et al. 2008 \\
\hline$n \mathrm{C}_{60}$ & $\begin{array}{c}\text { packed column } \\
\mathrm{H}: 15 \mathrm{~cm}, \mathrm{D}: 2.5 \mathrm{~cm}\end{array}$ & $\begin{array}{c}d_{D L S}=92 \mathrm{~nm} \text { (stock) } \\
3 \mathrm{mg} / \mathrm{L}\end{array}$ & $\begin{array}{c}\text { quartz sand } \\
d_{50}=125,335 \mu \mathrm{m}\end{array}$ & $\begin{array}{l}3,30 \mathrm{mM} \mathrm{NaCl}, \mathrm{pH} 7 \\
3,30 \mathrm{mM} \mathrm{CaCl}_{2}, \mathrm{pH} 7\end{array}$ & $\begin{array}{l}\text { Little } \mathrm{nC}_{60} \text { retention observed in coarser } \\
\text { sand at low IS; > 95\% retention at high IS } \\
\text { with finer sand (regardless of electrolyte) }\end{array}$ & Wang et al. 2008 \\
\hline $\begin{array}{l}\text { fullerols } \\
\mathrm{C}_{60}(\mathrm{OH})_{n}\end{array}$ & $\begin{array}{l}\text { packed column } \\
H: 10 \mathrm{~cm}, \mathrm{D}: 2.65 \mathrm{~cm}\end{array}$ & $\begin{array}{l}d_{D L S}=120 \mathrm{~nm} \\
18 \mathrm{mg} / \mathrm{L}\end{array}$ & $\begin{array}{l}\text { glass beads } \\
d_{50}=360 \mu \mathrm{m}\end{array}$ & $0.01-1 \mathrm{M} \mathrm{NaCl}, \mathrm{pH} 6.5-7.5$ & Increased deposition with increasing IS & Espinasse et al. 2007 \\
\hline $\begin{array}{l}\text { fullerols } \\
\mathrm{C}_{60}(\mathrm{OH})_{n}\end{array}$ & $\begin{array}{c}\text { packed column } \\
H: 9.25 \mathrm{~cm}, \mathrm{D}: 2.5 \mathrm{~cm}\end{array}$ & $\begin{array}{c}\mathrm{d}^{*}=1.2 \mathrm{~nm} \\
0-10 \mathrm{mg} / \mathrm{L} \text { (step function) }\end{array}$ & $\begin{array}{c}\text { glass beads } \\
d=300-425 \mu \mathrm{m}\left(d_{50}=355 \mu \mathrm{m}\right)\end{array}$ & $0.01 \mathrm{M} \mathrm{NaCl}, \mathrm{pH} 7$ & Fullerols have little affinity for porous media & Lecoanet et al. 2004 \\
\hline $\begin{array}{l}\text { fullerols } \\
\mathrm{C}_{60}(\mathrm{OH})_{n}\end{array}$ & $\begin{array}{c}\text { packed column } \\
\mathrm{H}: 9.25 \mathrm{~cm}, \mathrm{D}: 2.5 \mathrm{~cm}\end{array}$ & $\begin{array}{c}\mathrm{d}^{*}=1.2 \mathrm{~nm} \\
10 \mathrm{mg} / \mathrm{L}\end{array}$ & $\begin{array}{c}\text { glass beads } \\
d=300-425 \mu \mathrm{m}\left(d_{50}=355 \mu \mathrm{m}\right)\end{array}$ & $0.01 \mathrm{M} \mathrm{NaCl}, \mathrm{pH} 7$ & $\begin{array}{l}\text { Extremely low attachment levels; } 99 \% \\
\text { passage achieved at both flow velocities }\end{array}$ & $\begin{array}{c}\text { Lecoanet \& Wiesner, } \\
2004 \\
\end{array}$ \\
\hline $\mathrm{Pd}-n \mathrm{ZVI}$ & $\begin{array}{l}\text { subsurface delivery test site } \\
4.5 \times 3.0 \mathrm{~m}, 6 \mathrm{~m} \text { deep }\end{array}$ & $\begin{array}{c}d_{S E M}=100-200 \mathrm{~nm} \\
1.7 \mathrm{~kg} \text { nanoparticles injected }\end{array}$ & $\begin{array}{c}\text { aquifer } \\
\text { hydraulic conductivity }=0.2 \mathrm{~cm} / \mathrm{s} \\
\text { groundwater present }=14.1 \mathrm{~m}^{3}\end{array}$ & $\begin{array}{c}\text { groundwater: } \\
\text { pH 4.6-5.2 prior to injection } \\
\text { pH 5.1 - } 7.7 \text { post injection }\end{array}$ & $\begin{array}{c}\text { Pd-nZVI behavior in line with classical } \\
\text { colloid transport concepts and reactions in } \\
\text { porous media }\end{array}$ & Elliot \& Zhang, 2001 \\
\hline $\mathrm{Pd}-n \mathrm{ZVI}$ & $\begin{array}{c}\text { packed column } \\
H: 3.4 \mathrm{~cm}, \mathrm{D}: 1 \mathrm{~cm}\end{array}$ & $\begin{array}{c}\text { bare particles: } \\
\text { form dendritic flocs (TEM) } \\
\text { CMC-stabilized particles: } \\
\mathrm{d}_{\mathrm{TEM}}=4.3 \mathrm{~nm} \\
\mathrm{~d}_{\mathrm{DLS}}=17.2 \mathrm{~nm} \\
1 \mathrm{~g} / \mathrm{L}\end{array}$ & $\begin{array}{c}\text { soil } \\
\begin{array}{c}(84 \% \text { sand, } 10 \% \text { silt, } 6 \% \text { clay }) \\
d=n / a\end{array}\end{array}$ & $\begin{array}{l}\text { particle suspensions, } \mathrm{pH} 6.8,8.3 \\
\text { DI water to elute retained particles }\end{array}$ & $\begin{array}{l}\text { CMC-stabilized particles well dispersed in } \\
\text { soil; 98\% of stabilized Fe-Pd collected } \\
\text { from eluent (no irreversible binding) }\end{array}$ & He et al. 2007 \\
\hline$n \mathrm{ZVI}$ & $\begin{array}{c}\text { packed column } \\
\mathrm{H}:<100 \mathrm{~cm}, \mathrm{D}: 1.6 \mathrm{~cm}\end{array}$ & $\begin{array}{c}\mathrm{d}_{\text {TEM }}=50-100 \mathrm{~nm} \\
5 \mathrm{mg} / \mathrm{mL}\end{array}$ & $\begin{array}{c}\text { Ottawa sand } \\
\mathrm{d}=160 \pm 45 \mu \mathrm{m}\end{array}$ & $\begin{array}{c}\mathrm{PAA}+\mathrm{PSS}+\text { bentonite clay } \\
\text { mixtures, } \mathrm{pH}=\mathrm{n} / \mathrm{a}\end{array}$ & $\begin{array}{l}\text { Particle elution dependent on electrolyte } \\
\text { composition but not on total [poly(anion)]; } \\
\text { higher PSS and lower PAA and clay } \\
\text { concentrations result in highest elution }\end{array}$ & Hydutsky et al. 2007 \\
\hline$n \mathrm{ZVI}$ & $\begin{array}{l}\text { packed column } \\
\mathrm{H}: 10 \mathrm{~cm}, \mathrm{D}: 2.5 \mathrm{~cm} \\
\mathrm{H}: 50 \mathrm{~cm}, \mathrm{D}: 6 \mathrm{~cm} \\
\end{array}$ & $\begin{array}{c}\text { bare: } \mathrm{d}_{\mathrm{SEM}}=10-160 \mathrm{~nm} \\
\text { surfactant stabilized: } \mathrm{d}_{\mathrm{TEM}}=2-10 \mathrm{~nm} \\
1 \mathrm{~g} / \mathrm{L}\end{array}$ & $\begin{array}{l}\text { glass beads } \\
\text { sand (unbaked and baked) } \\
\text { all collector types: } d=425-600 \mu \mathrm{m}\end{array}$ & $\begin{array}{c}0.01 \mathrm{M} \mathrm{NaCl} \text { ( } \pm \text { surfactant) } \\
\mathrm{pH} 7\end{array}$ & $\begin{array}{l}\text { Adding surfactant, breakthrough occurs } \\
\text { earlier in column packed with glass beads; } \\
\text { nZVI is immobile in absence of surfactant }\end{array}$ & Kanel et al. 2007 \\
\hline$n Z \mathrm{VI}$ & $\begin{array}{c}\text { 2-D physical model } \\
L^{*}: 50 \mathrm{~cm}, \mathrm{~W}: 2 \mathrm{~cm}, \mathrm{H}: 28.5 \\
\mathrm{~cm}\end{array}$ & $\begin{array}{l}\text { size }=\mathrm{n} / \mathrm{a} \\
4 \mathrm{~g} / \mathrm{L}\end{array}$ & $\begin{array}{c}\text { silica beads } \\
d_{50}=1,100 \pm 100 \mu \mathrm{m}\end{array}$ & $\begin{array}{l}\text { freshwater } \\
\text { steady-state flow } \\
\mathrm{pH}=\text { n/a }\end{array}$ & $\begin{array}{l}\text { Nonstabilized nZVI not transported; PAA- } \\
\text { nZVI transported with negligible retardation; } \\
\text { transport influenced by density gradients }\end{array}$ & Kanel et al. 2008 \\
\hline$n Z \mathrm{VI}$ & $\begin{array}{c}\text { packed column } \\
\mathrm{H}: 25.5 \mathrm{~cm}, \mathrm{D}: 1.1 \mathrm{~cm}\end{array}$ & $\begin{array}{c}3 \text { particle fractions: } \\
\text { bimodal size distributions (DLS) } \\
0.03-6 \mathrm{~g} / \mathrm{L}\end{array}$ & $\begin{array}{l}\text { quartz sand } \\
d_{50}=300 \mu \mathrm{m}\end{array}$ & $\begin{array}{c}10 \mathrm{mM}\left(\mathrm{NaCl}+\mathrm{NaHCO}_{3}\right) \\
\mathrm{pH} 8\end{array}$ & $\begin{array}{l}\text { At } 0.03 \mathrm{~g} / \mathrm{L} \text { concentration, all modified nZVI } \\
\text { particles mobile; at higher concentrations, } \\
\text { larger particles with higher } \mathrm{Fe}^{0} \text { content } \\
\text { experience heightened deposition }\end{array}$ & Phenrat et al. 2009 \\
\hline$n Z \mathrm{VI}$ & $\begin{array}{l}\text { packed column + QCM-D } \\
H: 61.3 \mathrm{~cm}, \mathrm{D}: 1.1 \mathrm{~cm}\end{array}$ & $\begin{array}{c}\text { bare: } d_{D L S}=146 \mathrm{~nm} \\
\text { Triblock co-polym mod.: } \mathrm{d}_{\mathrm{DLS}}=212 \mathrm{~nm} \\
\text { PA mod.: } \mathrm{d}_{\mathrm{DLS}}=66 \mathrm{~nm} \\
\text { SDBS mod.: } \mathrm{d}_{\mathrm{DLS}}=190 \mathrm{~nm} \\
30 \mathrm{mg} / \mathrm{L}\end{array}$ & $\begin{array}{c}\text { quartz sand } \\
d_{50}=300 \mu \mathrm{m}\end{array}$ & $\begin{array}{l}1-1000 \mathrm{mM} \mathrm{NaCl}, \mathrm{pH} 7.7 \\
0.1-50 \mathrm{mM} \mathrm{CaCl} \\
2, \mathrm{pH} 7.7\end{array}$ & $\begin{array}{l}\text { Bare nZVI was immobile, while both PA and } \\
\text { SDBS-modified particles mobile at lower IS; } \\
\text { Triblock co-polymer-modified particles have } \\
\text { greatest mobility }\end{array}$ & Saleh et al. 2008 \\
\hline$n Z \mathrm{VI}$ & $\begin{array}{c}\text { packed column } \\
H: 13 \mathrm{~cm}, \mathrm{D}: 1.2 \mathrm{~cm}\end{array}$ & $\begin{array}{c}\text { carbon stabilized iron } \\
\mathrm{d}_{\mathrm{TEM}}=30-100 \mathrm{~nm} \\
5 \mathrm{mg} / \mathrm{mL}\end{array}$ & $\begin{array}{c}\text { Ottawa sand } \\
d=200-700 \mu \mathrm{m} \\
3 \text { soil types } \\
\text { loam, sandy loam, clay loam }\end{array}$ & Nanopure water, $\mathrm{pH} 6.7$ & $\begin{array}{c}\text { All collector types retain unsupported nZVl; } \\
\text { supported particle retention highest in loam } \\
\text { and sandy loam ( } \geq 80 \% \text { ); elution decreases } \\
\text { with time }\end{array}$ & Schrick et al. 2004 \\
\hline$n Z \mathrm{VI}$ & $\begin{array}{c}\text { packed column } \\
\mathrm{V}: 10 \mathrm{~mL} \text { (in } 50 \mathrm{~mL} \text { buret) }\end{array}$ & $\begin{array}{c}\text { bare: } \mathrm{d}^{*}=30-70 \mathrm{~nm} \\
\text { Fe-silica: } \mathrm{d}_{\mathrm{TEM}}=358 \pm 249 \mathrm{~nm} \\
3 \mathrm{~g} / \mathrm{L}\end{array}$ & $\begin{array}{l}\text { Ottawa sand } \\
d \geq 300 \mu \mathrm{m}\end{array}$ & $\begin{array}{l}\text { DI water } \\
\mathrm{pH}=\mathrm{n} / \mathrm{a}\end{array}$ & $\begin{array}{l}\text { Bare nZVI trapped in top portion of column; } \\
70 \% \text { of Fe-silica particles reach bottom of } \\
\text { column and elute }\end{array}$ & Zhan et al. 2008 \\
\hline
\end{tabular}




\begin{tabular}{|c|c|c|c|c|c|c|}
\hline$n Z \mathrm{ZVI}$ & $\begin{array}{l}\text { horizontal capillary tube } \\
\mathrm{H}: 3 \mathrm{~cm}, \mathrm{D}: 0.15-0.18 \mathrm{~cm}\end{array}$ & $\begin{array}{c}\text { bare: } \mathrm{d}^{\star}=30-70 \mathrm{~nm} \\
\text { Fe-silica: } \mathrm{d}_{\mathrm{TEM}}=358 \pm 249 \mathrm{~nm} \\
3 \mathrm{~g} / \mathrm{L}\end{array}$ & $\begin{array}{l}\text { Ottawa sand } \\
d \geq 300 \mu \mathrm{m}\end{array}$ & $\begin{array}{l}\text { DI water } \\
\mathrm{pH}=\mathrm{n} / \mathrm{a}\end{array}$ & $\begin{array}{l}\text { Bare nZVI aggregates accumulate at inlet; } \\
\text { Fe-silica particles form small clusters and } \\
\text { distribute uniformly throughout capillary }\end{array}$ & Zhan et al. 2008 \\
\hline $\begin{array}{l}\text { polystyrene latex } \\
\text { (sulfate-modified) }\end{array}$ & $\begin{array}{l}\text { packed column } \\
\mathrm{H}: 20 \mathrm{~cm}, \mathrm{D}: \mathrm{n} / \mathrm{a}\end{array}$ & $\begin{array}{l}\mathrm{d}^{*}=46 \mathrm{~nm} \\
1-4 \mathrm{mg} / \mathrm{L}\end{array}$ & $\begin{array}{l}\text { glass beads } \\
d=200,400 \mu \mathrm{m}\end{array}$ & $\begin{array}{c}3-300 \mathrm{mM} \mathrm{KCl}, \mathrm{pH}=6.7 \\
13-800 \mathrm{mM}\left(\mathrm{CaCl}_{2}+\mathrm{KCl}\right) \\
\mathrm{pH}=6.7\end{array}$ & $\begin{array}{c}\text { Deposition rates increase with increasing IS } \\
\text { until } 0.1 \mathrm{M} \mathrm{KCl} \text { and } 0.01 \mathrm{M} \mathrm{CaCl}_{2} \text { (above } \\
\text { which deposition rates drop off again) }\end{array}$ & $\begin{array}{l}\text { Elimelech \& O'Melia, } \\
1990\end{array}$ \\
\hline polystyrene latex & $\begin{array}{c}\text { packed column } \\
H: 15,20 \mathrm{~cm}, \mathrm{D}: \mathrm{n} / \mathrm{a}\end{array}$ & $\begin{array}{c}\mathrm{d}^{*}=46 \mathrm{~nm} \\
0.5 \mathrm{ppm}\end{array}$ & $\begin{array}{c}\text { glass beads } \\
\mathrm{d}=200,400 \mu \mathrm{m}\end{array}$ & 3 - 300 mM KCl, pH 6.7 & Deposition rates increase with increasing IS & $\begin{array}{l}\text { Elimelech \& O'Melia, } \\
1990 \\
\end{array}$ \\
\hline $\begin{array}{l}\text { polystyrene latex } \\
\text { (sulfate-modified) }\end{array}$ & $\begin{array}{l}\text { packed column } \\
\mathrm{H}: 25 \mathrm{~cm}, \mathrm{D}: 2.5 \mathrm{~cm}\end{array}$ & $\begin{aligned} & \mathrm{d}^{*}= \mathrm{d}_{\mathrm{DLS}}=98 \mathrm{~nm} \\
& 1 \mathrm{mg} / \mathrm{L}\end{aligned}$ & $\begin{array}{l}\text { glass beads } \\
d=200 \mu \mathrm{m}\end{array}$ & $\begin{array}{c}0-500 \mathrm{mM} \mathrm{NaCl} \pm 1 \mathrm{mg} \mathrm{C} / \mathrm{L} \\
\text { SRHA, pH } 7.2\end{array}$ & $\begin{array}{l}\text { Increased particle deposition with increasing } \\
\text { IS; particles depositing at lower IS more } \\
\text { prone to reentrainment; reduction in particle } \\
\text { deposition and enhanced reentrainment in } \\
\text { presence of SRHA }\end{array}$ & $\begin{array}{l}\text { Franchi \& O'Melia, } \\
\qquad 2003\end{array}$ \\
\hline $\begin{array}{l}\text { polystyrene latex } \\
\text { (sulfate modified) }\end{array}$ & $\begin{array}{c}\text { packed column } \\
H: 20 \mathrm{~cm}, \mathrm{D}: 2.5 \mathrm{~cm}\end{array}$ & $\begin{array}{c}\mathrm{d}^{*}=72 \mathrm{~nm} \\
1 \mathrm{mg} / \mathrm{L}\end{array}$ & $\begin{array}{l}\text { glass beads } \\
\mathrm{d}=400 \mu \mathrm{m}\end{array}$ & $0.01 \mathrm{M} \mathrm{NaClO}_{4}, \mathrm{pH} 10$ & $\begin{array}{c}\text { Latex particles exhibit little affinity for glass } \\
\text { beads }\end{array}$ & Hahn et al. 2004 \\
\hline polystyrene latex & $\begin{array}{c}\text { packed column } \\
\mathrm{H}: 20 \mathrm{~cm}, \mathrm{D}: 10 \mathrm{~cm}\end{array}$ & $\begin{array}{c}\mathrm{d}^{*}=53 \mathrm{~nm} \\
1 \mathrm{~mL} \text { pulse injection, } C=\mathrm{n} / \mathrm{a}\end{array}$ & $\begin{array}{l}\text { Munich gravel } \\
d=250 \mu \mathrm{m} \\
\text { Sengenthal sand } \\
d=100 \mu \mathrm{m}\end{array}$ & $\begin{array}{l}1,10 \mathrm{mM} \mathrm{NaCl}, \mathrm{pH}=\mathrm{n} / \mathrm{a} \\
1,10 \mathrm{mM} \mathrm{CaCl}_{2}, \mathrm{pH}=\mathrm{n} / \mathrm{a}\end{array}$ & $\begin{array}{l}\text { Deposition in agreement with DLVO theory; } \\
\text { particle elution increases with decreasing IS; } \\
\text { removal efficiency in sand more affected by } \\
\text { IS, impact of counterion valence more } \\
\text { apparent in gravel }\end{array}$ & Huber et al. 2000 \\
\hline $\begin{array}{l}\text { polystyrene latex } \\
\text { (sulfate-modified) }\end{array}$ & $\begin{array}{c}\text { packed column } \\
\mathrm{H}: 15-16.5 \mathrm{~cm}, \mathrm{D}: 1 \mathrm{~cm}\end{array}$ & $\begin{array}{c}\mathrm{d}^{*}=50 \mathrm{~nm} \\
\mathrm{C}=\mathrm{n} / \mathrm{a}\end{array}$ & $\begin{array}{c}\text { quartz sand } \\
d_{50}=256 \mu \mathrm{m}\end{array}$ & $\begin{array}{c}1-100 \mathrm{mM} \mathrm{KCl} \pm 5.0 \mathrm{mg} / \mathrm{L} \mathrm{SRHA}, \\
\mathrm{pH} 5.7\end{array}$ & $\begin{array}{c}\text { Increase in IS results in increased } \\
\text { attachment; addition of SRHA decreases } \\
\text { attachment }\end{array}$ & Pelley \& Tufenkji, 2008 \\
\hline $\begin{array}{c}\text { polystyrene latex } \\
\text { (carboxyl-modified) }\end{array}$ & $\begin{array}{c}\text { packed column } \\
\mathrm{H}: 20 \mathrm{~cm}, \mathrm{D}: 5.4 \mathrm{~cm}\end{array}$ & $\begin{array}{l}\quad d^{*}=20 \mathrm{~nm} \\
\text { pulse injection, } C=n / a\end{array}$ & $\begin{array}{l}\text { dune sand ( } 3 \text { preparations) } \\
\text { washing: none, } \mathrm{dH}_{2} \mathrm{O} \text {, acid } \\
\mathrm{d}_{50}=0.31-0.32 \mathrm{~mm} \\
\end{array}$ & $\begin{array}{l}\text { 3- } 4 \mathrm{mM} \text { artificial rainwater, } \\
\mathrm{pH} 7-8\end{array}$ & $\begin{array}{l}\text { Colloid retention greater in unwashed } \\
\text { (natural) sand than in washed types }\end{array}$ & Shani et al. 2008 \\
\hline $\begin{array}{c}\text { polystyrene latex } \\
\text { (carboxyl-modified) }\end{array}$ & $\begin{array}{l}\text { packed column } \\
H: 10 \mathrm{~cm}, \mathrm{D}: 3.8 \mathrm{~cm}\end{array}$ & $\begin{array}{c}\mathrm{d}^{*}=30,66 \mathrm{~nm} \\
10 \mathrm{mg} / \mathrm{L}\end{array}$ & $\begin{array}{l}\text { glass beads (3 fraction sizes) } \\
d=88-125 \mu \mathrm{m}, d_{50}=110 \mu \mathrm{m} \\
d=180-250 \mu \mathrm{m}, d_{50}=220 \mu \mathrm{m} \\
d=590-840 \mu \mathrm{m}, d_{50}=720 \mu \mathrm{m}\end{array}$ & $\begin{array}{c}\text { Dl water } \\
0.2 \mathrm{M} \mathrm{NaCl}, \mathrm{pH} 10\end{array}$ & $\begin{array}{l}\text { Using DI water, } 100 \% \text { nanoparticle elution } \\
\text { observed; addition of DI water to columns } \\
\text { run using NaCl releases colloids deposited } \\
\text { in secondary minima }\end{array}$ & Shen et al. 2008 \\
\hline $\begin{array}{c}\text { polystyrene latex } \\
\text { (carboxyl-modified) }\end{array}$ & $\begin{array}{c}\text { packed column } \\
\mathrm{H}: 12.6 \mathrm{~cm}, \mathrm{D}: 1.6 \mathrm{~cm} \\
\end{array}$ & $\begin{array}{c}\mathrm{d}^{*}=63 \mathrm{~nm} \\
3.6 \times 10^{8}-3.6 \times 10^{9} \text { particles } / \mathrm{mL}\end{array}$ & $\begin{array}{l}\text { glass beads } \\
d_{50}=330 \mu \mathrm{m}\end{array}$ & $\begin{array}{c}20-200 \mathrm{mM} \mathrm{KCl} \\
\mathrm{pH} 8,11\end{array}$ & $\begin{array}{l}\text { Increasing IS results in a marked increase in } \\
\text { retention }\end{array}$ & $\begin{array}{l}\text { Tufenkii \& Elimelech, } \\
2005\end{array}$ \\
\hline $\begin{array}{l}\text { chloromethyl latex } \\
\text { (sulfate-modified) }\end{array}$ & $\begin{array}{c}\text { packed column } \\
\mathrm{H}: 10 \mathrm{~cm}, \mathrm{D}: 4.5 \mathrm{~cm} \\
\text { saturated and unsaturated } \\
\text { conditions } \\
\end{array}$ & $\begin{array}{c}\mathrm{d}^{*}=20,100 \mathrm{~nm} \\
100 \mathrm{mg} / \mathrm{L}\end{array}$ & $\begin{array}{c}\text { quartz sand } \\
d=300-355 \mu \mathrm{m}\end{array}$ & $\begin{array}{c}1 \mathrm{mM}\left(\mathrm{NaCl}+\mathrm{NaHCO}_{3}\right) \\
\mathrm{pH} 7.5\end{array}$ & $\begin{array}{l}\text { Transport is size dependent under saturated } \\
\text { and unsaturated conditions; colloid retention } \\
\text { sensitive to saturation }\end{array}$ & Zhuang et al. 2005 \\
\hline QDs & QCM-D & $\begin{array}{c}\mathrm{d}^{*}=10 \mathrm{~nm} \\
\mathrm{~d}_{\mathrm{DLS}}=45-100 \mathrm{~nm} \\
0.96 \mathrm{mg} / \mathrm{mL}\end{array}$ & silica surface & $\begin{array}{c}1-300 \mathrm{mM} \mathrm{KCl}, \mathrm{pH} 5,7 \\
17 \mathrm{mM} \mathrm{CaCl} \\
2, \mathrm{pH} 5\end{array}$ & $\begin{array}{l}\text { Heightened QD deposition in presence of } \\
\mathrm{Ca}^{2+}\left(\mathrm{vs} \mathrm{K}^{+}\right) \text {and at } \mathrm{pH} 5(\mathrm{vs} \mathrm{pH} 7)\end{array}$ & $\begin{array}{l}\text { Quevedo \& Tufenkij, } \\
\qquad 2009\end{array}$ \\
\hline$n S \mathrm{iO}_{2}$ & $\begin{array}{l}\text { packed column } \\
H: 9.25 \mathrm{~cm}, \mathrm{D}: 2.5 \mathrm{~cm}\end{array}$ & $\begin{array}{c}2 \text { particle sizes } \\
\text { type 1: } d_{\text {DLS }}=57 \mathrm{~nm}, \mathrm{~d}^{\star}=47 \mathrm{~nm} \\
\text { type 2: } d_{\text {DLS }}=135 \mathrm{~nm}, \mathrm{~d}^{\star}=103 \mathrm{~nm} \\
0-10 \mathrm{mg} / \mathrm{L}\end{array}$ & $\begin{array}{c}\text { glass beads } \\
300-425 \mu \mathrm{m}\left(d_{50}=355 \mu \mathrm{m}\right)\end{array}$ & $0.01 \mathrm{M} \mathrm{NaCl}, \mathrm{pH} 7$ & $\begin{array}{l}\text { Smaller silica particles very mobile with low } \\
\text { affinity for collector; heightened retention } \\
\text { with larger particles }\end{array}$ & Lecoanet et al. 2004 \\
\hline$n \mathrm{SiO}_{2}$ & $\begin{array}{c}\text { packed column } \\
H: 9.25 \mathrm{~cm}, \mathrm{D}: 2.5 \mathrm{~cm} \\
\end{array}$ & $\begin{array}{c}d_{D L S}=57 \mathrm{~nm} \\
10 \mathrm{mg} / \mathrm{L}\end{array}$ & $\begin{array}{c}\text { glass beads } \\
300-425 \mu \mathrm{m}\left(\mathrm{d}_{50}=355 \mu \mathrm{m}\right)\end{array}$ & $0.01 \mathrm{M} \mathrm{NaCl}, \mathrm{pH} 7$ & $\begin{array}{l}\text { Very low retention; flow rate has no } \\
\text { significant impact on silica removal }\end{array}$ & $\begin{array}{l}\text { Lecoanet \& Wiesner, } \\
2004\end{array}$ \\
\hline SWNTs & $\begin{array}{l}\text { packed column } \\
\mathrm{H}: 6.3 \mathrm{~cm}, \mathrm{D}: 1.6 \mathrm{~cm}\end{array}$ & $\begin{array}{c}\mathrm{d}_{\mathrm{RS}}=0.9-1.6 \mathrm{~nm} \\
87 \mathrm{mg} / \mathrm{L}\end{array}$ & $\begin{array}{c}\text { quartz sand } \\
d=225-300 \mu \mathrm{m}\left(d_{50}=263 \mu \mathrm{m}\right) \\
(\text { bare and silanized })\end{array}$ & $\begin{array}{c}0.1-55 \mathrm{mM} \mathrm{KCl} \pm 5 \mathrm{mg} / \mathrm{L} \mathrm{SRHA}, \\
\mathrm{pH} 7.0 \\
10 \mathrm{mM}\left(\mathrm{KCl}+\mathrm{CaCl}_{2}\right) \pm 5 \mathrm{mg} / \mathrm{L} \\
\mathrm{SRHA}, \mathrm{pH} 7.0 \\
\end{array}$ & $\begin{array}{l}\text { Results consistent with DLVO theory; SWNT } \\
\text { straining restricts mobility at low IS }\end{array}$ & Jaisi et al. 2008 \\
\hline
\end{tabular}




\begin{tabular}{|c|c|c|c|c|c|c|}
\hline SWNTs & $\begin{array}{l}\text { packed column } \\
H: 4.3 \mathrm{~cm}, D: 1.6 \mathrm{~cm}\end{array}$ & $\begin{array}{c}d_{D L S}=244 \mathrm{~nm} \\
7-125 \mu \mathrm{g} \text { (pulse injection) }\end{array}$ & $\begin{array}{c}\text { soil } \\
\text { (58\% sand, } 29 \% \text { clay, } 13 \% \text { silt) } \\
d=0.42-1.0 \mathrm{~mm}\end{array}$ & $\begin{array}{c}0.1-100 \mathrm{mM} \mathrm{KCl}, \mathrm{pH} 5.6-5.8 \\
0.03-10 \mathrm{mM} \mathrm{CaCl}, \mathrm{pH} 5.6-5.8\end{array}$ & $\begin{array}{l}\text { High retention with little change above } 0.3 \\
\mathrm{mM} \mathrm{KCl} \text { or } 0.1 \mathrm{mM} \mathrm{CaCl} \text {; physical straining } \\
\text { plays important role in SWNT deposition }\end{array}$ & Jaisi \& Elimelech, 2009 \\
\hline SWNTs & $\begin{array}{c}\text { packed column } \\
H: 9.25 \mathrm{~cm}, \mathrm{D}: 2.5 \mathrm{~cm}\end{array}$ & $\begin{array}{c}\mathrm{d}^{*}=0.7-1.1 \mathrm{~nm} \\
\mathrm{~L}=80-200 \mathrm{~nm} \\
\mathrm{~d}_{\mathrm{DLS}}=21 \mathrm{~nm} \\
0-10 \mathrm{mg} / \mathrm{L}\end{array}$ & $\begin{array}{c}\text { glass beads } \\
300-425 \mu \mathrm{m}\left(d_{50}=355 \mu \mathrm{m}\right)\end{array}$ & $0.01 \mathrm{M} \mathrm{NaCl}, \mathrm{pH} 7$ & SWNTs show little affinity for porous media & Lecoanet et al. 2004 \\
\hline SWNTs & $\begin{array}{c}\text { packed column } \\
H: 9.25 \mathrm{~cm}, \mathrm{D}: 2.5 \mathrm{~cm}\end{array}$ & $\begin{array}{c}\mathrm{d}^{*}=0.7-1.1 \mathrm{~nm} \\
\mathrm{~L}=80-200 \mathrm{~nm} \\
\mathrm{~d}_{\mathrm{DLS}}=21 \mathrm{~nm} \\
10 \mathrm{mg} / \mathrm{L}\end{array}$ & $\begin{array}{c}\text { glass beads } \\
300-425 \mu \mathrm{m}\left(d_{50}=355 \mu \mathrm{m}\right)\end{array}$ & $0.01 \mathrm{M} \mathrm{NaCl}, \mathrm{pH} 7$ & $\begin{array}{l}\text { Extremely low attachment; increased velocity } \\
\text { alters breakthrough curve appearance }\end{array}$ & $\begin{array}{l}\text { Lecoanet \& Wiesner, } \\
2004\end{array}$ \\
\hline MWNTs & $\begin{array}{l}\text { packed column } \\
H: 10 \mathrm{~cm}, \mathrm{D}: 5 \mathrm{~cm}\end{array}$ & $\begin{array}{c}d_{T E M}=7-70 \mathrm{~nm} \\
\mathrm{~L}_{S E M}=100 \mathrm{~nm}-2 \mu \mathrm{m}, \text { avg. } 407 \mathrm{~nm} \\
100 \mathrm{mg} / \mathrm{L}\end{array}$ & $\begin{array}{c}\text { quartz sand } \\
d_{50}=476 \mu \mathrm{m} \\
\text { glass beads } \\
d=425-500 \mu \mathrm{m}\end{array}$ & $\begin{array}{c}10 \mathrm{mM} \text { solution }\left(\mathrm{NaHCO}_{3}+\right. \\
\left.\mathrm{Na}_{2} \mathrm{CO}_{3}+\mathrm{NaBr} \text { or } \mathrm{NaCl}\right), \mathrm{pH} 10 \\
0.1 \mathrm{mM} \mathrm{NaOH} \text { solution, } \mathrm{pH} 10\end{array}$ & $\begin{array}{c}\text { Breakthrough at } 43,21 \text { and } 4.0 \mathrm{~m} / \mathrm{d} \text { similar, } \\
\text { with time-dependent } \mathrm{C} / \mathrm{Co} \text {; particle mobility } \\
\text { likely enhanced beyond critical pore water } \\
\text { velocity }\end{array}$ & Xueying et al. 2009 \\
\hline SWNTs \& MWNTs & $\begin{array}{c}\text { packed column } \\
H: 15 \mathrm{~cm}, \mathrm{D}: 2.5 \mathrm{~cm}\end{array}$ & $\begin{aligned} \text { SWNTs: } \mathrm{d}^{*}=1.4 \mathrm{~nm} \\
\text { MWNTs: } \mathrm{d}^{*}=35 \pm 10 \mathrm{~nm} \\
\mathrm{C}=\mathrm{n} / \mathrm{a}\end{aligned}$ & $\begin{array}{c}\text { quartz sand } \\
d_{50}=350 \mu \mathrm{m}\end{array}$ & $\begin{array}{c}0.01-10 \mathrm{mM} \mathrm{KCl} \\
0.01-10 \mathrm{mM} \mathrm{CaCl} \\
\mathrm{pH}=\mathrm{n} / \mathrm{a} \\
\end{array}$ & $\begin{array}{c}\text { Filtration of MWNTs higher than SWNTs; } \\
\text { straining insignificant }\end{array}$ & Wang et al. 2008 \\
\hline$n \mathrm{TiO}_{2}$ & $\begin{array}{c}\text { soil cell } \\
H: 1.27 \mathrm{~cm}, \mathrm{D}: 2.54 \mathrm{~cm}\end{array}$ & $\begin{array}{c}\mathrm{d}^{*}=21 \mathrm{~nm} \\
\mathrm{~d}_{\mathrm{DLS}}=123.2 \pm 7.6 \mathrm{~nm} \\
25 \mathrm{mg} / \mathrm{L}\end{array}$ & $\begin{array}{l}\text { glass beads } \\
\mathrm{d}=500 \mu \mathrm{m}\end{array}$ & $0.2 \mathrm{mM} \mathrm{NaCl}, \mathrm{pH} 10$ & $\begin{array}{l}\text { Considers unsaturated } \mathrm{nTiO}_{2} \text { transport; } \\
\text { increased retention with decreasing } \\
\text { saturation and slower drainage rates }\end{array}$ & Chen et al. 2008 \\
\hline$n \mathrm{TiO}_{2}$ & $\begin{array}{l}\text { packed column } \\
H: 30 \mathrm{~cm}, \mathrm{D}: 15 \mathrm{~cm}\end{array}$ & $\begin{array}{c}d_{\text {AFM }}<0.1 \mu \mathrm{m} \\
50,75,100 \mathrm{mg} / \mathrm{L}\end{array}$ & $\begin{array}{l}\text { quartz sand } \\
d_{50}=20 \mu \mathrm{m}\end{array}$ & $0.01 \mathrm{M} \mathrm{NaCl}, \mathrm{pH}=4.5$ & $\begin{array}{l}\text { Very high particle retention; existing models } \\
\text { limited in ability to predict } \mathrm{nTi}_{2} \text { behavior }\end{array}$ & Choy et al. 2008 \\
\hline$n \mathrm{TiO}_{2}$ & $\begin{array}{c}\text { pyrex wafers } \\
\text { (2-D microchannel model) } \\
\mathrm{L}^{*}: 7.0 \mathrm{~cm}, \mathrm{~W}: 3.0 \mathrm{~cm}, \mathrm{H}: \\
87-92 \mu \mathrm{m} \\
\end{array}$ & $\begin{array}{c}\mathrm{d}_{\mathrm{XRD}}=5-12 \mathrm{~nm} \\
\mathrm{~d}_{\mathrm{DLS}} \text { depends on pH } \\
0.07-0.14 \mathrm{~g} / \mathrm{L} \\
\end{array}$ & $\begin{array}{c}\text { pyrex } \\
d=700 \mu \mathrm{m}\end{array}$ & $\begin{array}{l}\text { hydrolysis synthesis solution, } \\
\qquad \mathrm{pH} 1-12\end{array}$ & $\begin{array}{l}\text { Suspended nanoparticle aggregates very } \\
\text { mobile; lower mobility seen at } \mathrm{pH} 3 \text { and } 7 \\
\text { (aggregates settle at } \mathrm{pH} 7 \text { ) }\end{array}$ & Guzman et al. 2006 \\
\hline$n \mathrm{TiO}_{2}$ & $\begin{array}{c}\text { packed column } \\
\mathrm{H}: 10 \mathrm{~cm}, \mathrm{D}: 2.5 \mathrm{~cm}\end{array}$ & $\begin{aligned} & d_{50}=35 \mathrm{~nm} \\
& 2 \mathrm{~g} / \mathrm{L}\end{aligned}$ & $\begin{array}{l}12 \text { surface soil types } \\
d_{50}=30-132 \mu \mathrm{m}\end{array}$ & $\begin{array}{c}0.15-4.95 \mathrm{mM} \text { soil suspensions, } \\
\mathrm{pH} 6.2-8.6\end{array}$ & $\begin{array}{c}\mathrm{nTiO}_{2} \text { most mobile in soil solutions with } \\
\text { smaller grain diameters and lower IS; } \\
\text { heightened retention with increasing clay } \\
\text { content and salinity }\end{array}$ & Fang et al. 2009 \\
\hline$n \mathrm{TiO}_{2}$ & QCM-D & $\begin{array}{c}d^{*}=5 \mathrm{~nm} \\
d_{D L S}=350-750 \mathrm{~nm} ; d_{F C S}=7-189 \mathrm{~nm} \\
d_{A F M}=30 \mathrm{~nm} \\
d_{\text {TEM }} \sim 30 \mathrm{~nm} \text { with larger aggregates } \\
10 \mathrm{mg} / \mathrm{L}\end{array}$ & silica surface & $\begin{array}{c}1-100 \mathrm{mM} \mathrm{NaNO}_{3} \\
\quad \mathrm{pH} 3,5,9\end{array}$ & $\begin{array}{l}\text { Strong attractive electrostatic interactions } \\
\text { between silica and } \mathrm{nTi}_{2} \text { at } \mathrm{pH} 3,5 \text { and at } \\
\text { low IS; generally good agreement with } \\
\text { DLVO theory }\end{array}$ & Fatisson et al. 2009 \\
\hline$n \mathrm{TiO}_{2}$ & $\begin{array}{c}\text { packed column } \\
H: 10 \mathrm{~cm}, \mathrm{D}: 1.1 \mathrm{~cm}\end{array}$ & $\begin{array}{c}\mathrm{d}^{*}=10 \mathrm{~nm} \\
\text { bare: } \mathrm{d}_{\mathrm{TEM}}=14 \pm 1 \mathrm{~nm} \\
\text { CMC-modified: } \mathrm{d}_{\mathrm{TEM}}=15 \pm 1 \mathrm{~nm} \\
\mathrm{~d}_{\mathrm{DLS}} \text { varies with solution chemistry } \\
20 \mathrm{mg} / \mathrm{L}\end{array}$ & $\begin{array}{c}\text { quartz sand } \\
\mathrm{d}_{50}=290 \mu \mathrm{m} \pm \text { aluminum or iron } \\
\text { hydroxide coating }\end{array}$ & $\begin{array}{c}\text { ultrapure water } \\
1,30 \mathrm{mM} \mathrm{NaCl}, \mathrm{pH} 5.5-7.6 \\
30 \mathrm{mM} \mathrm{CaCl} \\
2, \mathrm{pH}=7.1\end{array}$ & $\begin{array}{l}\mathrm{CMC} \text { coating greatly enhances mobility } \\
\text { (bare } \mathrm{nTiO}_{2} \text { is immobile) }\end{array}$ & Sung et al. 2009 \\
\hline$n \mathrm{TiO}_{2}$ & $\begin{array}{c}\text { packed column } \\
H: 9.25 \mathrm{~cm}, \mathrm{D}: 2.5 \mathrm{~cm}\end{array}$ & $\begin{aligned} \mathrm{d}^{*} & =40 \mathrm{~nm} \\
\mathrm{~d}_{\mathrm{DLS}} & =198 \mathrm{~nm} \\
0 & -10 \mathrm{mg} / \mathrm{L}\end{aligned}$ & $\begin{array}{c}\text { glass beads } \\
300-425 \mu \mathrm{m}\left(\mathrm{d}_{50}=355 \mu \mathrm{m}\right)\end{array}$ & $0.01 \mathrm{M} \mathrm{NaCl}, \mathrm{pH} 7$ & $\begin{array}{l}\mathrm{nTiO}_{2} \text { exhibits greater retention than } \\
\text { alumoxane but more mobile than ferroxane; } \\
\text { mobility slightly increasing with time }\end{array}$ & Lecoanet et al. 2004 \\
\hline$n \mathrm{TiO}_{2}$ & $\begin{array}{l}\text { packed column } \\
H: 9.25 \mathrm{~cm}, \mathrm{D}: 2.5 \mathrm{~cm}\end{array}$ & $\begin{aligned} & \mathrm{d}^{*}=40 \mathrm{~nm} \\
& \mathrm{~d}_{\mathrm{DLS}}=198 \mathrm{~nm} \\
& 10 \mathrm{mg} / \mathrm{L}\end{aligned}$ & $\begin{array}{c}\text { glass beads } \\
300-425 \mu \mathrm{m}\left(\mathrm{d}_{50}=355 \mu \mathrm{m}\right)\end{array}$ & $0.01 \mathrm{M} \mathrm{NaCl}, \mathrm{pH} 7$ & $\begin{array}{l}\text { Decreased } \mathrm{nTiO}_{2} \text { retention at faster flow } \\
\text { velocity }\end{array}$ & $\begin{array}{l}\text { Lecoanet \& Wiesner, } \\
2004\end{array}$ \\
\hline$n \mathrm{TiO}_{2}$ & $\begin{array}{c}\text { packed column } \\
H: 100 \mathrm{~cm}, \mathrm{D}: 1.27 \mathrm{~cm}\end{array}$ & $\begin{array}{l}\mathrm{d}^{*}=40-60 \mathrm{~nm} \text { (before functionalization) } \\
\text { Injected as } \sim 60 \text { wt\% aqueous slurry }\end{array}$ & $\begin{array}{l}\text { quartz sand } \\
20-30 \text { mesh }\end{array}$ & $\begin{array}{c}\sim 60 \text { wt } \% \mathrm{TiO}_{2} \text { aqueous slurry }+ \\
2 \% \text { ammonium carboxylate } \\
\mathrm{pH}=\mathrm{n} / \mathrm{a}\end{array}$ & $\begin{array}{l}\text { Functionalized } \mathrm{nTiO}_{2} \text { distributed uniformly } \\
\text { throughout column, } \mathrm{Cu} \text {-EDA functionalized } \\
\mathrm{nTiO}_{2} \text { candidate for groundwater treatment }\end{array}$ & Mattigod et al. 2005 \\
\hline
\end{tabular}


Figure 1. Representative aggregation stability curves for selected engineered nanomaterials: (a) $n \mathrm{C}_{60}$ and $n \mathrm{C}_{60}$ derivatives PCBM ([6,6]-phenyl $\mathrm{C}_{61}$-butyric acid methyl ester) and the corresponding butyl and octyl esters, PCBB and PCBO, and (b) MWNTs and surface oxidized MWNTs with varying surface oxygen concentration (SOC). Experimental data adapted from $(14,16-18,23,24,34)$.

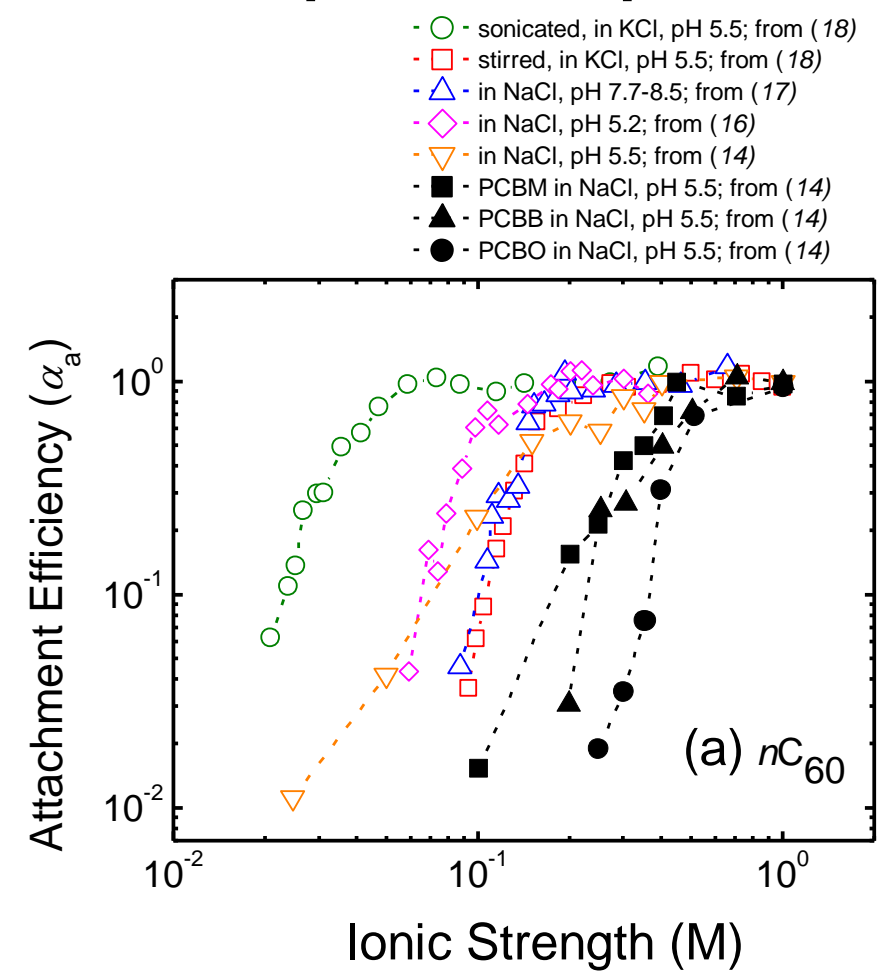

- $\bigcirc$ - in $\mathrm{NaCl}$ pH 6; from (34)

$-\triangle-4.3 \%$ SOC, in $\mathrm{NaCl} \mathrm{pH} 6$; from (24)

$-\triangle-5.3 \%$ SOC, in $\mathrm{NaCl} \mathrm{pH} 6$; from (24)

$-\nabla=7.6 \%$ SOC, in $\mathrm{NaCl}$ pH 6 ; from (24)

$-D-9.5 \%$ SOC, in $\mathrm{NaCl} \mathrm{pH} 6$; from (24)

$-\square-1-8 \%$ SOC, in $\mathrm{NaCl} \mathrm{pH}$ 3; from (23)

- $-1-8 \%$ SOC, in $\mathrm{NaCl}$ pH 6; from (23)

- $1-8 \%$ SOC, in $\mathrm{NaCl} \mathrm{pH} 10$; from (23)

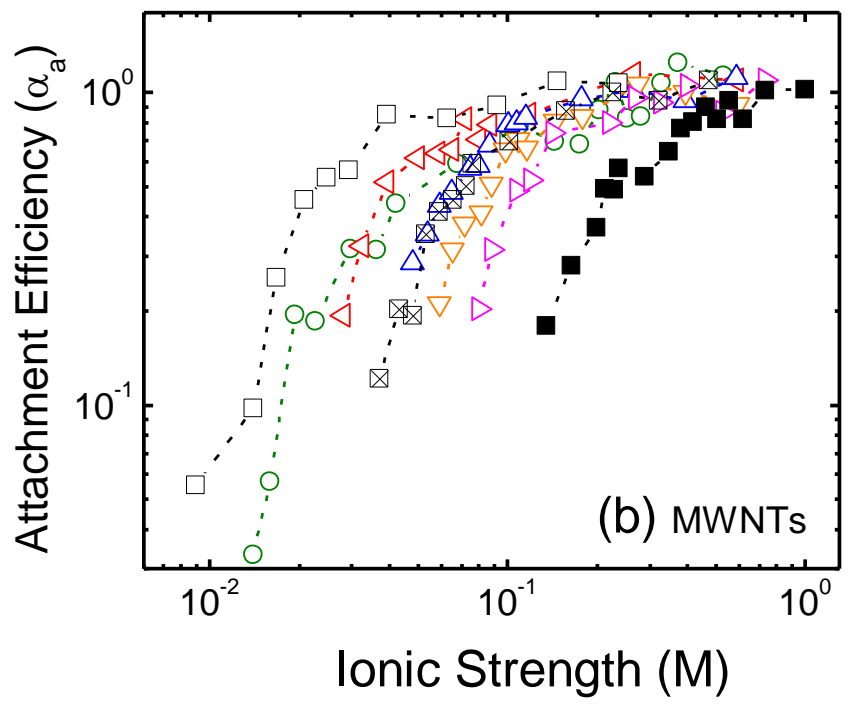


Figure 2. Representative deposition stability curves for selected engineered nanomaterials, including $n \mathrm{~B}, n \mathrm{C}_{60}$, carboxyl-modified latex (CML), sulfate-modified latex (SML), $n$ ZVI, and SWNTs. Experimental data adapted from $(20,62,65,67,73,83,86,91)$.

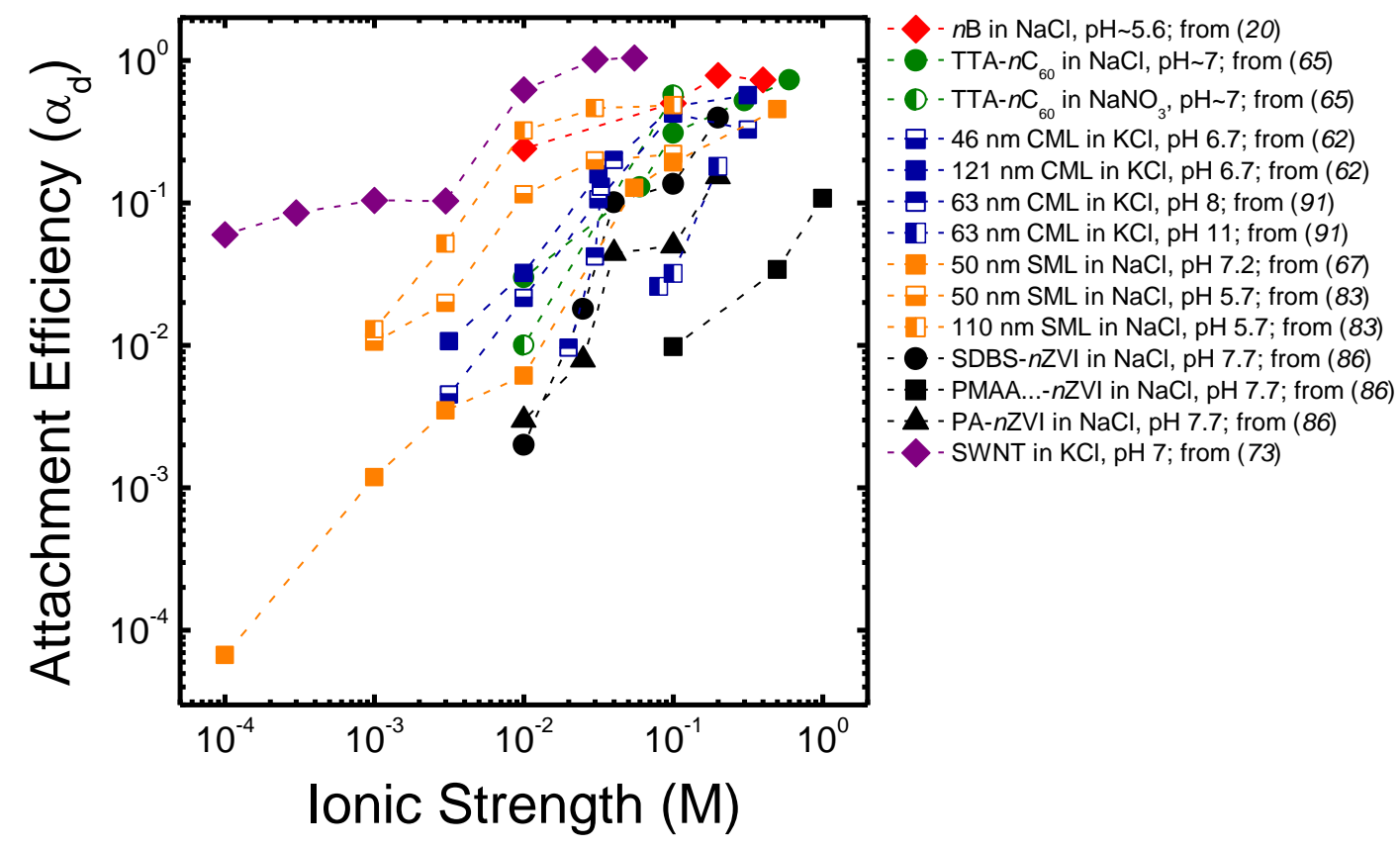




\section{BRIEF}

A comprehensive overview of theoretical and experimental approaches pertaining to nanomaterial transport and aggregation in aquatic environments emphasizing the role of physicochemical interactions. 